\title{
Catalytic Hydrogen Production from Bioethanol
}

\author{
Hua Song \\ RTI International \\ USA
}

\section{Introduction}

Along with the maturity of the production technology (i.e., fermentation) for a long history, bioethanol has become one of the most significant chemicals and energy carriers in large quantity derived from biomass. Although ethanol production from non-food resources remains challengeable for scientists, how to utilize ethanol in an efficient and economical way opens more space for all researchers both from industry and academia to play with.

Hydrogen is likely to play an important role in the energy portfolio of the future due to its high gravimetric energy density. Especially when it is used in fuel cells, it is an ideal energy carrier that can offer clean and efficient power generation. In the United States, $~ 95 \%$ of hydrogen is produced using a steam reforming process [1]. Over $50 \%$ of world's hydrogen production relies on natural gas as the feedstock [2]. As the concern for a sustainable energy strategy grows, replacing natural gas and other fossil fuels with renewable sources is gaining new urgency. In this context, producing hydrogen from bio-derived liquids such as bio-ethanol has emerged as a promising technology due to the low toxicity, ease of handling and the availability from many different renewable sources (e.g., sugar cane, switchgrass, algae) that ethanol has to offer. An added advantage of producing hydrogen from bioderived liquids is that it is quite suitable for a distributed production strategy.

This chapter is aimed to provide a big overview of the current technologies for catalytic hydrogen production from bioethanol while focusing the discussion on the hydrogen production through steam reforming of bioethanol over non-precious metal based catalysts, more specifically, cobalt-based catalysts. By combing the work performed at the author' laboratories, this chapter will also provide the professional insights on the future development direction of such technologies. Through the estimated economic analysis of this process simulated at industrial scale, the ways of final commercialization of the developed catalyst system specially tailored for central and distributed hydrogen production from steam reforming of bioethanol will be suggested.

\section{Production technology overview}

Multiple techniques have been developed during the past decades to convert bioethanol to hydrogen by following the reaction (1).

$$
\mathrm{C}_{2} \mathrm{H}_{5} \mathrm{OH}_{(\mathrm{l})}+3 \mathrm{H}_{2} \mathrm{O}_{(\mathrm{l})} \quad 2 \mathrm{CO}_{2}+6 \mathrm{H}_{2} \quad\left(\Delta \mathrm{H}_{\mathrm{r}, 298 \mathrm{~K}}=348 \mathrm{~kJ} / \mathrm{mol}\right)
$$


It is clearly observed that 6 moles of hydrogen can be produced per mole of ethanol fed. However, the highly endothermic feature of this reaction requires external energy supply. Depending on the type of energy input, the current hydrogen production technologies can be categorized into two areas: non-thermal including bio, photo, plasma, and thermalchemical processes. Besides, several hybrid systems have also been recently developed to produce hydrogen relying on the energy supply of more than one source (e.g., photofermentation and thermal plasma). Compared to thermochemical conversion, non-thermal hydrogen production can take place at much mild conditions with minimal thermo-energy input requirement from surroundings. However, the biological or photo hydrogen production efficiency is much lower than acceptable scale for industrial application. Unlike biological or photo process, thermochemical conversion can happen at much higher reaction rate, but under relatively severe conditions (e.g., high temperature and pressure) with notable amount of thermo-energy input. In addition to water, $\mathrm{CO}_{2}$ (dry reforming) and $\mathrm{O}_{2}$ (partial oxidation or oxidative reforming) can also act as oxidant to oxidize ethanol for hydrogen production. Among all the available techniques described in details in this section, steam reforming might possess the highest potential to be commercialized in the near term.

\subsection{Fermentative hydrogen production}

In this process, metabolically engineered microorganisms such as bacteria convert ethanol to hydrogen under the facilitation of hydrogenase enzymes which are metalloproteins, containing complicated metal active centres that catalyze the interconversion of protons and electrons with dihydrogen. According to literature reporting [3-5], two major classes of hydrogenases are recognized based on their metal active sites: [FeFe] and [NiFe]. Depending on whether light will be involved, this biological hydrogen production process can be simply classified as photo- and dark-fermentation processes [6].

During the photo-fermentation process, the hydrogenase enzyme synthesized and activated under dark anaerobic condition is used to convert ethanol to biohydrogen under light anaerobic condition. Since the light acts as the energy source, the consumption rate of substrate is less than that required for dark fermentation. However, the hydrogen efficiency will be dramatically reduced in the presence of oxygen concurrently produced through photosynthesis by bacteria, which has been evidenced by many researchers [7]. Furthermore, the ultra-violet wavelength radiation requirement and relatively slower production rate limit its industrial application at large scale.

Under the dark operation environment, there is no risk for hydrogenases exposed to oxygen, which makes the hydrogenase enzymes remain active throughout the whole process, leading to more efficient hydrogen production. Compared to photo-fermentation, the inherent continuous and fast production feature makes dark anaerobic digestion economically promising for industrial scale practice. In recent years, many publications have reported their efforts spent on optimization of operation parameters, development of genetically modified microorganism, metabolic engineering, improvement of reactor designs, use of different solid matrices for cell immobilization, etc. to maximize hydrogen yield. Among many considerations, the blockage of methanogenesis in the anaerobic pathway is crucial to improve hydrogen selectivity through the inhibition of methane formation. 


\subsection{Photocatalytic hydrogen production}

In addition to biological process, photocatalytic oxidation of ethanol provides alternative interesting approach to generate hydrogen. Similar to photo-fermentation where enzyme is used to catalyze the conversion, solar energy is again utilized to offer sufficient power to produce hydrogen from ethanol under the facilitation of inorganic catalyst. Among many catalysts documented in the literature, $\mathrm{TiO}_{2}[8-10]$ is the most commonly used catalyst base due to its excellent photoreactivity which has a suitable band gap for efficient light photon absorption. Upon radiation, the electron contained in a semiconductor such as $\mathrm{TiO}_{2}$ will be excited and transferred from valence band to conduction band, resulting in the creation of an electron-hole pair and in turn providing an active site for redox reaction. As shown in Figure 1 , reaction (1) is a typical redox reaction where $\mathrm{H}_{2} \mathrm{O}$ serves as the oxidant to oxidize ethanol while itself being reduced to $\mathrm{H}_{2}$. The adsorbed ethanol and water species will react with each other on the surface of the active sites of the synthesized photocatalyst to produce $\mathrm{H}_{2}$. Usually, certain amount of active metal (noble metal or transition metal) will be loaded to the $\mathrm{TiO}_{2}$ support to promote its photoactivity. According to the publications, $\mathrm{Cu}, \mathrm{Ni}, \mathrm{V}$, $\mathrm{Pt}, \mathrm{Pd}, \mathrm{Rh}, \mathrm{Au}, \mathrm{Ir}$, and Ru have been tested [11-14], among which $\mathrm{Pt}$ doped $\mathrm{TiO}_{2}$ exhibits the highest photoactivity toward hydrogen production from bioethanol. Various synthesis methods have been successfully demonstrated to get $\mathrm{TiO}_{2}$ supported catalyst with desirable particle size and morphology for hydrogen generation maximization. Besides $\mathrm{TiO}_{2}$ supported catalyst, there are multiple other novel semiconductors being developed recently for effective hydrogen production including $\mathrm{CdS}$ [15], $\mathrm{VO}_{2}$ [16], $\mathrm{WO}_{3}$ [17], and $\mathrm{ZnSn}(\mathrm{OH})_{6}$ [18]. Nevertheless, the hydrogen production efficiency from catalytic ethanol oxidation still remains at very low level probably due to two facts: the fast recombination rate of the created electron-hole pairs and the low photon absorption efficiency at visible light range. Although hydrogen evolution rate of $21 \mathrm{mmol} / \mathrm{g}_{\text {cat }} / \mathrm{h}$ has been reported and is the fastest rate claimed so far in the literature [19], it is still significantly lower than that obtained from thermochemical ethanol conversion. Therefore, the technical breakthrough is required in the field of photocatalysis before the commercialization of this technique can be seriously considered.

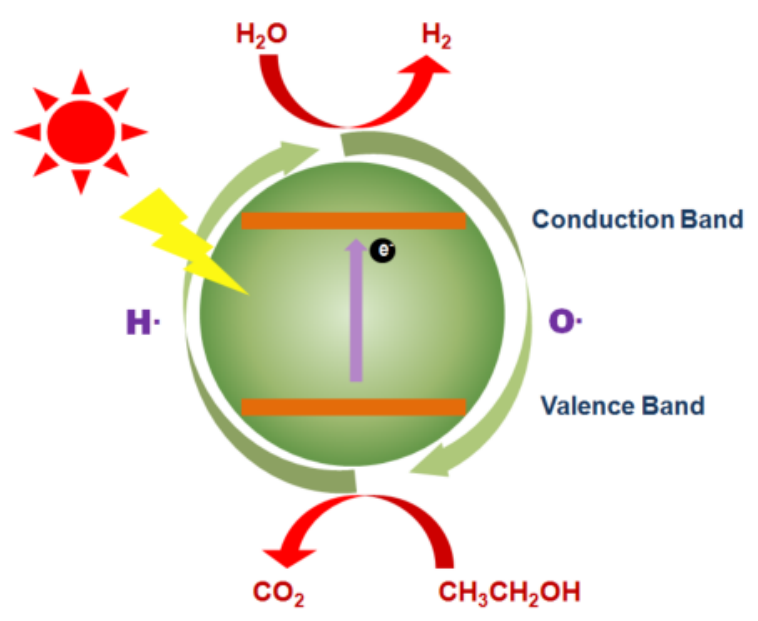

Fig. 1. The schematic diagram of photocatalytic ethanol reforming 


\subsection{Aqueous phase reforming}

As a low temperature alternative to steam reforming, Aqueous Phase Reforming (APR) has emerged as a valuable means of converting organic compounds of biological origin to valueadded chemicals and fuel components. Due to its feature of low temperature operation, the energy required for water and oxygenated hydrocarbon evaporation is eliminated, leading to the notable reduction of overall energy input, which overcomes the evaporation difficulty of some organic compounds with high boiling point required for steam reforming. In order to keep all reactants in the liquid phase at operation temperature (typically $\sim 500 \mathrm{~K}$ ), certain pressure (typically 15 50 bar) has to be applied to the whole reactor system. Such operation temperature and pressure benefit the happening of water-gas shift reaction, making it possible to produce hydrogen with low amounts of $\mathrm{CO}$ in a single reactor. Undesirable organic compound decomposition can also be minimized under such low reaction temperature. Furthermore, the relatively high pressure operation will also favour the downstream gas separation and purification, and even subsequent gas compression, storage, and delivery. This process is exclusively suitable for the biomass derived organic compounds with relatively longer carbon chain such as sorbitol, which has been comprehensively reviewed by the researchers in Dumesic's group [20]. For smaller organic compounds like ethanol discussed in this chapter, APR process for hydrogen generation is less favourable from the overall energy utilization viewpoint, which is concluded by Tokarev, et al. in their recent publication [21]. Moreover, the relatively high pressure requirement raises the concerns on safety and operation cost. Hydrogen selectivity is another big challenge APR has to face, because $\mathrm{H}_{2}$ and $\mathrm{CO}_{2}$ produced are thermodynamically unstable and methane formation is favourable at such low temperature.

\section{$2.4 \mathrm{CO}_{2}$ dry reforming}

In addition to $\mathrm{H}_{2} \mathrm{O}, \mathrm{CO}_{2}$ can also acts as oxidant to reform ethanol to generate gaseous products. The reaction involved in this process is depicted in Reaction (2).

$$
\mathrm{C}_{2} \mathrm{H}_{5} \mathrm{OH}_{(\mathrm{l})}+\mathrm{CO}_{2} \quad 3 \mathrm{H}_{2}+3 \mathrm{CO} \quad\left(\Delta \mathrm{H}_{\mathrm{r}, 298 \mathrm{~K}}=338 \mathrm{~kJ} / \mathrm{mol}\right)
$$

Compared to Reaction (1), although only 3 moles of hydrogen are produced per mole of ethanol by using dry reforming process, it is still a valuable approach to utilize $\mathrm{CO}_{2}$ for hydrogen or syngas production beneficial for reducing greenhouse gas emission. The process feasibility and optimal operation parameters have been investigated by W. Wang, et al. thermodynamically, which is valuable for desirable product yield maximization. According to the calculations performed in [22], higher temperature, lower pressure, addition of inert gas, and lower $\mathrm{CO}_{2}$ to ethanol ratio benefit the improvement of hydrogen yield. Several catalysts such as $\mathrm{Ni} / \mathrm{Al}_{2} \mathrm{O}_{3}$ [23] and $\mathrm{Rh} / \mathrm{CeO}_{2}$ [24] have been developed in recent years for hydrogen or syngas production. Generally speaking, $\mathrm{CO}_{2}$ is less active than water in oxidizing ethanol. Therefore, more active catalysts are critical for making ethanol dry reforming more attractive to industrial investors. Similarly to methane dry reforming, coke can be formed with high possbility at certain reaction conditions on the catalyst surface, resulting in catalyst deactivation. Carbon tends to form at low temperature and low $\mathrm{CO}_{2}$ /ethanol ratio based on thermodynamic prediction, which should be avoided to prevent catalyst deactivation. However, sometimes as a preferable byproducts, production of various types of carbon nanofilaments is desired by following Reaction (3), which has been found to be effectively catalyzed by stainless steel or carbon steel catalysts $[25,26]$. 


$$
\mathrm{C}_{2} \mathrm{H}_{5} \mathrm{OH}_{(\mathrm{l})}+\mathrm{CO}_{2} \quad 2 \mathrm{H}_{2}+2 \mathrm{CO}+2 \mathrm{C}+\mathrm{H}_{2} \mathrm{O}_{(\mathrm{l})} \quad\left(\Delta \mathrm{H}_{\mathrm{r}, 298 \mathrm{~K}}=163 \mathrm{~kJ} / \mathrm{mol}\right)
$$

\subsection{Plasma reforming}

The energy required for ethanol reforming can also be provided by the electrical discharge powered by high voltage transformer. The ethanol solution fed can thereafter be ionized to plasma state under such discharge, leading to the creation of a variety of chemically active species and energetic electrons which will quickly react with each other to form product gases. Depending on their energy level, temperature, and electronic density, plasma state can be generally classified as thermal and non-thermal plasma. Compared to thermal plasma, the hydrogen production under non-thermal plasma condition has much lower energy consumption. The features of low temperature operation, rapid reaction start-up, no involvement of catalyst handling, and non-equilibrium properties make non-thermal plasma technique very promising for energy conversion and fuel gas treatment [27]. Comparable performance has been reported through non-thermal plasma process toward hydrogen production, which is very close to the ones obtained from catalytic reactors [28]. However, its relatively high energy requirement, complicated reaction network, and low selectivity remain the main obstacles preventing it from industrial application at current stage.

\subsection{Partial oxidation}

Compared to $\mathrm{H}_{2} \mathrm{O}$ and $\mathrm{CO}_{2}, \mathrm{O}_{2}$ is much active in partially oxidizing ethanol for hydrogen production by following a representative Reaction (4) which is a slightly endothermic reaction, indicating that much less external energy is needed for reaction proceeding.

$$
\mathrm{C}_{2} \mathrm{H}_{5} \mathrm{OH}_{(\mathrm{l})}+0.5 \mathrm{O}_{2} \quad 3 \mathrm{H}_{2}+2 \mathrm{CO} \quad\left(\Delta \mathrm{H}_{\mathrm{r}, 298 \mathrm{~K}}=56 \mathrm{~kJ} / \mathrm{mol}\right)
$$

As a result, the ethanol partial oxidation can take place at much lower temperature (200 $\sim 300{ }^{\circ} \mathrm{C}$ ) in the presence of catalyst than those required for steam or dry reforming (typically $450 \sim 650 \circ \mathrm{C})$. Depending on the reaction conditions and catalyst used, in addition to CO, various ethanol oxidation products with different oxidation states have been observed including acetaldehyde, acetone, acetic acid, and $\mathrm{CO}_{2}$. Plenty of catalyst systems have been extensively studied for catalyzing ethanol oxidation at low temperature. Among them, NiFe alloy [29] from transition metal group and Pt from noble metal group based catalyst [30] have drawn special attentions. According to literature reporting, 51\% ethanol conversion and $97 \%$ hydrogen selectivity has been successfully achieved at temperature as low as $370 \mathrm{~K}$ over $\mathrm{Pt} / \mathrm{ZrO}_{2}$ [31]. Although $\mathrm{O}_{2}$ usage significantly improves the ethanol reactivity and lowers down the energy input, it reduces the hydrogen production by half, referring to Reaction (1). Moreover, the likelihood of hot-spot formation makes the control of this reaction difficult.

\subsection{Steam reforming}

As mentioned earlier in this chapter, hydrogen production can be maximized per fed ethanol through pure steam reforming. However, the highly endothermic feature of this reaction limits its widely industrial application for hydrogen production. In order to lessen its heavy dependence on external energy supply, part of ethanol is sacrificed to provide required energy for steam reforming through the introduction of oxygen, which is named as oxidative steam reforming (Reaction 5). Depending on the value of $\delta$, the enthalpy change of 
Reaction (5) will become less positive, indicating less energy requirement from surroundings. The reaction will finally become autothermal at the point where little or no energy is needed from external sources (e.g., if $\delta=0.6, \Delta \mathrm{H}_{\mathrm{r}, 298 \mathrm{~K}}=4.4 \mathrm{~kJ} / \mathrm{mol}$ ).

$$
\mathrm{C}_{2} \mathrm{H}_{5} \mathrm{OH}_{(\mathrm{l})}+\delta \mathrm{O}_{2}+(3-2 \delta) \mathrm{H}_{2} \mathrm{O}_{(\mathrm{l})} \quad(6-2 \delta) \mathrm{H}_{2}+2 \mathrm{CO}_{2}
$$

Although the products from the desired reactions are only $\mathrm{CO}_{2}$ and $\mathrm{H}_{2}$, in reality, depending on the reaction conditions and catalysts used, the product distribution can be governed by a very complex reaction network. Possible reactions involved can be as follows.

$$
\begin{aligned}
& \mathrm{CH}_{3} \mathrm{CH}_{2} \mathrm{OH} \quad \mathrm{CH}_{4}+\mathrm{CO}+\mathrm{H}_{2} \quad \text { (ethanol decomposition) } \\
& \mathrm{CH}_{3} \mathrm{CH}_{2} \mathrm{OH} \quad \mathrm{CH}_{3} \mathrm{CHO}+\mathrm{H}_{2} \quad \text { (ethanol dehydrogenation) } \\
& \mathrm{CH}_{3} \mathrm{CH}_{2} \mathrm{OH} \quad \mathrm{C}_{2} \mathrm{H}_{4}+\mathrm{H}_{2} \mathrm{O} \quad \text { (ethanol dehydration) } \\
& \mathrm{CH}_{3} \mathrm{CH}_{2} \mathrm{OH}+\mathrm{H}_{2} \mathrm{O} \quad 2 \mathrm{CO}+4 \mathrm{H}_{2} \quad \text { (ethanol incomplete reforming) } \\
& 2 \mathrm{CH}_{3} \mathrm{CH}_{2} \mathrm{OH} \quad\left(\mathrm{C}_{2} \mathrm{H}_{5}\right)_{2} \mathrm{O}+\mathrm{H}_{2} \mathrm{O} \quad \text { (ethanol dehydrative coupling) } \\
& \mathrm{CH}_{3} \mathrm{CH}_{2} \mathrm{OH}+\mathrm{H}_{2} \mathrm{O} \quad \mathrm{CH}_{3} \mathrm{COOH}+2 \mathrm{H}_{2} \quad \text { (acetic acid formation) } \\
& \mathrm{CH}_{3} \mathrm{CHO} \quad \mathrm{CH}_{4}+\mathrm{CO} \text { (acetaldehyde decomposition) } \\
& 2 \mathrm{CH}_{3} \mathrm{CHO} \quad \mathrm{CH}_{3} \mathrm{COCH}_{3}+\mathrm{CO}+\mathrm{H}_{2} \text { (acetone formation) } \\
& \mathrm{CO}+3 \mathrm{H}_{2} \quad \mathrm{CH}_{4}+\mathrm{H}_{2} \mathrm{O} \quad \text { (methanation) } \\
& \mathrm{C}_{2} \mathrm{H}_{4} \quad \text { coke (polymerization) } \\
& \mathrm{CH}_{4}+2 \mathrm{H}_{2} \mathrm{O} \quad \mathrm{CO}_{2}+4 \mathrm{H}_{2} \quad \text { (methane steam reforming) } 1 \\
& \mathrm{CH}_{4} \quad \mathrm{C}+2 \mathrm{H}_{2} \quad \text { (methane cracking) } \\
& \mathrm{CO}+\mathrm{H}_{2} \mathrm{O} \leftrightarrows \mathrm{CO}_{2}+\mathrm{H}_{2} \quad \text { (water-gas shift) } \\
& 2 \mathrm{CO} \quad \mathrm{CO}_{2}+\mathrm{C} \quad \text { (Boudouard reaction) }
\end{aligned}
$$

There are many side reactions that might take place during ethanol steam reforming, complicating the product distribution. To get the highest possible $\mathrm{H}_{2}$ yield for industrial applications, it is essential to investigate the effects of temperature, reactants ratio, pressure, space velocity as well the catalytic parameters. A thermodynamic analysis was performed using the software HSC ${ }^{\circledR}$ Chemistry 5.1. All possible products, including solid carbon were included among the possible species that could exist in the equilibrium state. In the thermodynamic analysis, the following definitions are used.

$$
\mathrm{H}_{2} \text { Yield } \%=\frac{\text { moles of } \mathrm{H}_{2} \text { produced }}{6 \times(\text { moles of ethanol fed })} \times 100
$$




$$
\begin{aligned}
& \text { Selectivity } \%=\frac{\text { mol of a certain product }}{\text { mol of total products }} \times 100 \\
& \text { EtOH Conv. } \%=\frac{\text { moles of ethanol converted }}{\text { moles of ethanol fed }} \times 100
\end{aligned}
$$

The thermodynamic analysis in Fig.2 shows ethanol conversion, yield and selectivity of main products starting from a reactant composition similar to a bio-ethanol stream from biomass fermentation (ethanol-to-water ratio of 1:10). Ethanol conversion is not thermodynamically limited at any temperature. The methanation reaction, which is exothermic, is thermodynamically favored at lower temperatures (below $400 \circ \mathrm{C}$ ). At higher temperatures (above $500{ }^{\circ} \mathrm{C}$ ) the reverse of this reaction, i.e., steam reforming of methane to $\mathrm{CO}_{2}$ and $\mathrm{H}_{2}$ becomes favorable. This would suggest that, if operated in a thermodynamically controlled regime, in order to minimize $\mathrm{CH}_{4}$ concentration in the product stream, the reaction temperature should be kept as high as possible. However, as shown in Fig.2, once the temperature is increased above $550{ }^{\circ} \mathrm{C}$, the reverse-water-gas shift reaction takes off, i.e., $\mathrm{CO}$ formation becomes significant and hydrogen yield decreases. At this ethanol-to-water ratio, there is no solid carbon at the equilibrium state.

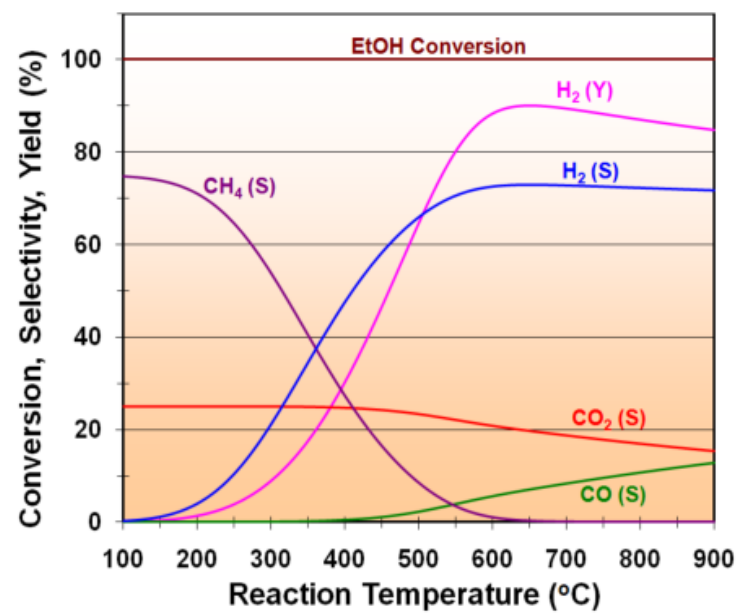

Fig. 2. Product distribution from ethanol steam reforming at thermodynamic equilibrium with EtOH:Water $=1: 10$ (molar), $\mathrm{C}_{\mathrm{EtOH}}=2.8 \%$, and atmospheric pressure

Fig. 3 shows the effect of ethanol-to-water molar ratio on $\mathrm{H}_{2}$ yield. Lower molar ratios of ethanol-to-water can increase the hydrogen yield, since both water gas shift reaction and $\mathrm{CH}_{4}$ reforming reactions would shift to the left with increased water concentration. In Fig.3, solid carbon selectivities for the lowest water concentrations are also included. At high ethanol-to-water ratios, solid carbon deposition becomes thermodynamically favorable, especially at lower temperatures.

The effect of dilution with an inert gas on the equilibrium $\mathrm{H}_{2}$ yield is shown in Fig.4. The addition of inert gas increases the equilibrium hydrogen yield at low temperatures and has no effect at high temperatures. At low temperatures, the dominant reaction is the methanation/methane steam reforming. Diluting the system favors the methane steam 
reforming, and hence we see a difference at low temperatures. At high temperatures, the main reaction is the reverse water gas shift reaction, which is not affected by dilution, since there is no change in the number of moles with the extent of this reaction. Increased pressure has a negative influence on hydrogen yield at lower temperatures and no effect at higher temperatures (Fig.5).

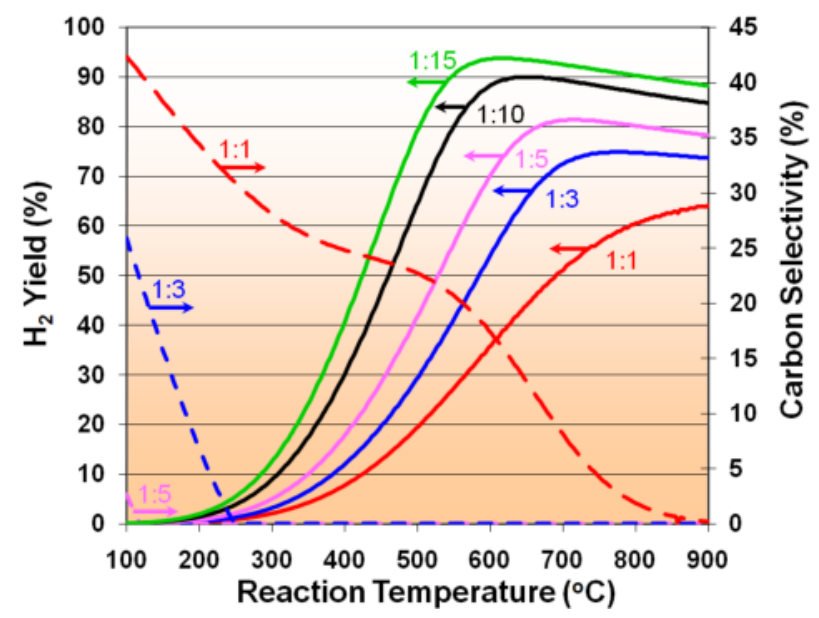

Fig. 3. Effect of EtOH-to-water molar ratio on equilibrium $\mathrm{H}_{2}$ yield and $\mathrm{C}$ selectivity at (no dilution)

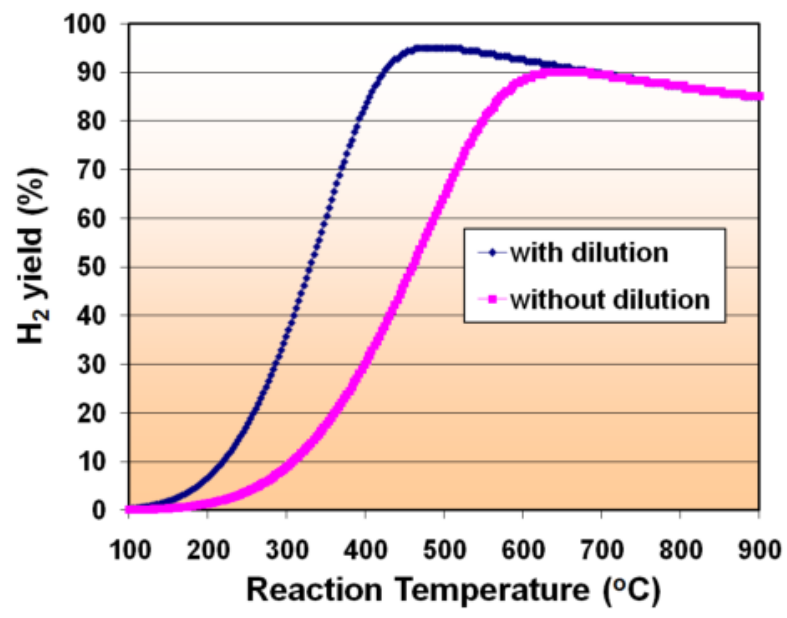

Fig. 4. Effect of dilution on equilibrium hydrogen yield (Dilution ratio used: Inert:EtOH: $\mathrm{H}_{2} \mathrm{O}$ $=25: 1: 10$ )

Although it is important to be aware of the thermodynamic limitations, these analyses do not provide any information about the product distribution that would be obtained under kinetically controlled regimes. However, the study is still meaningful for guiding the choice 
of the desirable reaction parameters such that reaction is always controlled by kinetics under thermodynamically favorable conditions.

Due to its simplicity, flexibility, maturity, and high hydrogen yield, thermal bioethanol steam reforming has been extensively studied and a variety of technical improvements and researches directions have been proposed and implemented over the past several decades. The discussions of the following sections will focus on this technique.

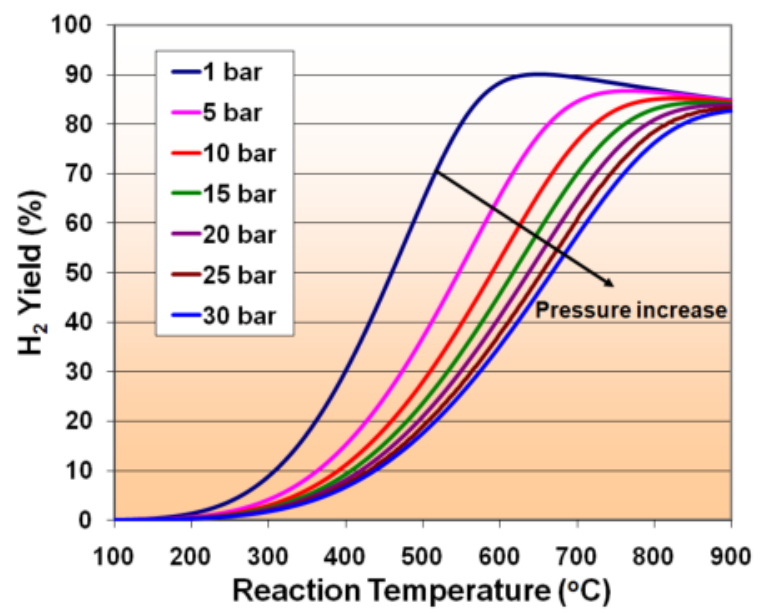

Fig. 5. Effect of pressure on equilibrium hydrogen yield (EtOH:Water=1:10 (molar ratio), no dilution)

\section{Catalyst overview}

In order to achieve equilibrated or even higher hydrogen yield especially at lower temperatures, catalytic bio-ethanol steam reforming (BESR) has been studied increasingly in recent years. More than three hundreds papers have been devoted to this field within the last two decades. The catalyst systems developed in these studies can be generally classified into two categories, i.e., supported noble and non-noble metal catalysts [32, 33]. However, based on the results reported in the literature, there is no commonly accepted optimal catalyst system which has excellent performance as well as low cost.

The noble metal catalysts such as Rh, Ru, Pd, Pt, Re, Au, and Ir [34-39] have been extensively investigated for BESR, which exhibit promising catalytic activity within a wide range of temperatures $\left(350{ }^{\circ} \mathrm{C} \sim 800{ }^{\circ} \mathrm{C}\right.$ ) and gas hourly space velocities (GHSV: 5,000 300,000 $\mathrm{h}^{-1}$ ). The outstanding catalytic performance experienced by noble metal catalysts might be closely related to its remarkable capability in C-C bond cleavage [40]. Among the noble metal catalysts reported so far, it is evidenced [41-44] that $\mathrm{Rh}$ is generally more effective than other noble metals in terms of ethanol conversion and hydrogen production. Diagne et al. [45] claimed that up to $5.7 \mathrm{~mol} \mathrm{H}_{2}$ can be produced per mol ethanol (equal to $95 \% \mathrm{H}_{2}$ yield) at $350 \circ \mathrm{C}-450 \circ \mathrm{C}$ over $\mathrm{CeO}_{2}-\mathrm{ZrO}_{2}$ supported $\mathrm{Rh}$ catalyst. However, although the metal loading is relatively low (1 5 wt.\%) compared with its non-noble counterparts (10 15 wt.\%), the extremely high unit price still limits its wide-scale industrial applications. 
As a less expensive alternative way to address the cost issue, increasing attention has been focused on the development of non-noble metal catalysts. According to the publications documented so far, the efforts are mainly focused on the $\mathrm{Cu}, \mathrm{Ni}$, and $\mathrm{Co}$ based catalyst systems, especially supported $\mathrm{Ni}$ catalysts. As typical transition metals, the active outer layer electrons and associated valence states determine their identities as the candidates for BESR. Similar with noble metals, Ni also works well as it favors C-C rupture. Based on the observations reported by several authors [38, 43,46], the non-precious metals are less reactive than noble metal supported samples. Specifically, $\mathrm{Rh}$ sites resulted to be 3.7 and 5.8 times more active than $\mathrm{Co}$ and $\mathrm{Ni}$, respectively, supported by $\mathrm{MgO}$ under the reaction conditions used in [43]. For obtaining the same reactivity $\left(\mathrm{H}_{2}\right.$ yield $\left.>95 \%\right)$, much higher temperatures $\left(650{ }^{\circ} \mathrm{C}\right)$ have to be employed $[43,47]$ over Ni catalysts. Furthermore, the nonnoble metals are more prone to be deactivated due to sintering and coking compared with $\mathrm{Rh}$. In order to achieve the comparable catalytic performance with noble metals, the formulation modifications of non-noble metal catalyst systems are worth studying for future commercialization. After summarizing the papers dedicated to investigation of various supports, $\mathrm{ZnO}$ and $\mathrm{La}_{2} \mathrm{O}_{3}$ seem more promising than $\mathrm{MgO}, \mathrm{Y}_{2} \mathrm{O}_{3}$, and $\mathrm{Al}_{2} \mathrm{O}_{3}$ in terms of activity and stability $[48,49]$. The basicity of sample surface has been evidenced crucial to improve its stability by adding $\mathrm{La}_{2} \mathrm{O}_{3}$ into the $\mathrm{Al}_{2} \mathrm{O}_{3}$ support aiming to neutralize the acidic sites present on the $\mathrm{Al}_{2} \mathrm{O}_{3}$ surface [50]. The addition of alkali metals (e.g., $\mathrm{Na}, \mathrm{K}$ ) to Ni/MgO has been observed to depress the deactivation occurrence by preventing Ni sintering [51]. It is worth noting that the recent interests on $\mathrm{Ni}$ catalysts seem to be transferred to $\mathrm{CeO}_{2}$ and $\mathrm{ZrO}_{2}$ supported samples, which could be ascribed to its well-known oxygen mobility, oxygen storage capability (OSC), and thermal stability [52-55], in turn improving cokeresistance. In addition, the synergetic effects become notable leading to better catalytic performance (activity, selectivity, and stability) when the second component $(\mathrm{Cu})$ is incorporated into the Ni catalysts indicated by the work performed by Fierro et al., Marino et al., and Velu et al. [56-58]. They believe that the introduction of $\mathrm{Cu}$ might favor the dehydrogenation of ethanol to acetaldehyde, one of the important surface reaction intermediates during BESR. Compared with Ni based catalysts, cobalt samples have been less studied as catalysts for BESR. However, recent years have witnessed a significant increase in publications focusing on the development of Co-based catalysts, among which is the pioneering work by Haga et al. [59, 60]. Then Llorca et al. reported the promising results that $5.1 \mathrm{~mol}$ of $\mathrm{H}_{2}$ can be produced per mol of reacted ethanol over $\mathrm{Co} / \mathrm{ZnO}$ sample [61]. Although the reaction condition is slightly unrealistic for industrial applications, this study proved that cobalt is also efficient in $\mathrm{C}-\mathrm{C}$ bond breakage [62]. Neither copper nor nickel alone supported on zinc oxide appears to have as good reactivity and stability as that of its Co counterpart for hydrogen production under the same reaction conditions $[63,64]$. After thorough investigation of the product distribution at various temperatures, it was indicated that the copper sample prefers dehydrogenation of ethanol into acetaldehyde but the reforming reaction does not further progress significantly into $\mathrm{H}_{2}$ and $\mathrm{CO}_{x}$. On the other hand, the nickel sample favors the decomposition reaction of ethanol to $\mathrm{CH}_{4}$ and $\mathrm{CO}_{\mathrm{x}}$, accounting for the lower $\mathrm{H}_{2}$ yield at lower temperatures. Only at high temperatures can the methane production be lowered through steam-reforming. Moreover, Co catalysts have been applied in the Fischer-Tropsch to generate liquid hydrocarbons for more than 80 years. The knowledge accumulated during the study of Co based catalyst systems provides a good starting point. With these encouraging initial data, cobalt catalysts merit to be studied extensively as an alternative solution for reducing the cost from usage of noble metals. 


\section{Catalyst optimization strategies}

In order to acquire competitive catalytic performance with noble metals, a series of optimization procedures need to be carried out over cobalt based catalysts. The significance of support was first explored by Haga et al. [59] indicating that $\mathrm{Co} / \mathrm{Al}_{2} \mathrm{O}_{3}$ shows more promising activity than $\mathrm{SiO}_{2}, \mathrm{C}, \mathrm{ZrO}_{2}$, and $\mathrm{MgO}$. A relatively systematic investigation of the effect of supports was performed by Llorca and his coworkers [65]. Among the supports of $\mathrm{CeO}_{2}, \mathrm{Sm}_{2} \mathrm{O}_{3}, \mathrm{MgO}, \mathrm{Al}_{2} \mathrm{O}_{3}, \mathrm{SiO}_{2}, \mathrm{TiO}_{2}, \mathrm{ZnO}, \mathrm{La}_{2} \mathrm{O}_{3}, \mathrm{~V}_{2} \mathrm{O}_{5}$ reported in this study, $\mathrm{ZnO}$ was ranked the best.

Recently mixed metal oxides have been employed as the support to improve the behavior of single metal oxides by doping one or more additional components into the original support lattice. For instance, in the implementation of $\mathrm{Ce}_{1-\mathrm{x}} \mathrm{Zr}_{\mathrm{x}} \mathrm{O}_{2}$, as the washcoat material in threeway catalysts, support combines the oxygen mobility of $\mathrm{CeO}_{2}$ and thermal tolerance of $\mathrm{ZrO}_{2}$ [66-69]. The introduction of Ca creates oxygen vacancies, which is beneficial for the enhancement of oxygen mobility [70,71]. Besides, the perovskite-type oxides such as $\mathrm{LaAlO}_{3}, \mathrm{SrTiO}_{3}$, and $\mathrm{BaTiO}_{3}$ have been used as the support for BESR catalysts due to their highly labile lattice oxygen $[72,73]$.

The cobalt precursor was proved by several authors [60, 74, 75] to have prominent effect on catalytic performance, which was proposed to be related to the cobalt dispersion. From the comparison between several precursor candidates, the one complexed with organic functional groups gave higher dispersion, which could be attributed to its isolation effect on the nearby Co atoms from agglomeration. It has been accepted that the active site during bio-ethanol steam reforming is related to the metal cobalt [76], that is, the higher the percentage of the cobalt that is available, the better the catalytic performance for BESR. Therefore, the improvement of cobalt dispersion will benefit the enhancement of corresponding catalytic activity.

It is expectable that cobalt loading has direct impact on the cobalt dispersion in the final catalyst. From the studies performed over Ni-based catalysts [53, 77], there exists an optimal loading, which can obtain the highest metal dispersion, through increasing the metal loading while avoiding metal sintering occurring at high loading due to the agglomeration of nearby metal atoms during thermal treatment. To the best of our knowledge, there is no systematic research of the effect of cobalt loading on its catalytic performance during BESR. Therefore, executing such a study can provide us better control of the catalyst optimization.

The impregnation medium is expected to have influence on the diffusion of cobalt precursor during impregnation and redistribution of cobalt atoms during the subsequent thermal treatment, which is shown by the experimental observations over $\mathrm{Co} / \mathrm{SiO}_{2}$ [78]. The smaller $\mathrm{Co}_{3} \mathrm{O}_{4}$ crystallite size obtained for samples using ethanol rather than water as impregnation solvent is attributed to the formation of ethoxyl groups on silica and/or $\mathrm{Co}_{3} \mathrm{O}_{4}$ surface during impregnation which hindered the sintering of $\mathrm{Co}_{3} \mathrm{O}_{4}$ by physically interfering during the thermal decomposition of nitrates. As a result, a higher percentage dispersion of cobalt metal was achieved from reduction of smaller crystallites of $\mathrm{Co}_{3} \mathrm{O}_{4}$. In addition, further sintering of cobalt metal during reduction might be hindered by ethoxyl groups as well. Since the cobalt dispersion is closely correlated to the activity during BESR as described above, this effect needs to be further investigated.

It was reported by Enache et al. [79] and Ruckenstein [80] in their studies of cobalt-based catalysts for Fischer-Tropsch reaction that the parameters used in the sample heat treatment 
before being charged for reaction play a significant role on the cobalt dispersion and in turn catalytic activity. Thus the synthesis parameters during calcination and reduction need to be explored to optimize the catalytic performance.

The promotion effect of alkali metal addition has been observed separately by Llorca et al., and Galetti et al. [63, 64, 81]. The hydrogen yield enhancement and carbon deposition inhibition showed the improvement of catalytic performance even when a small amount of $\mathrm{Na}$ and $\mathrm{K}(\sim 0.7 \mathrm{wt} . \%)$ was introduced. As an inexpensive additive, this promising modification should be further explored.

Similar to Ni catalysts, promotion effect has also been evidenced over the samples with the formation of metallic alloy. According to the results published so far, the second active metal in addition to Co can be generally categorized as noble metals (e.g., $\mathrm{Rh}$ [82] and $\mathrm{Ru}$ [83-85]) and non-noble metals (e.g., Ni, Cu [63, 86], Fe, and Mn [87]). The integration of each metal specialized in different functions might be responsible for the synergetic interaction on the improvement of catalytic performance. The non-noble metal additives also merit further investigation.

Not only the modifications to the formulation of catalyst system, but also the preparation methods can impact the catalytic performance. Versatile synthesis strategies have been developed for obtaining catalysts with high performance during BESR. Incipient wetness impregnation (IWI) [88-91], wet impregnation [84, 92, 93], sol-gel (SG) [94, 95], and coprecipitation (CP) $[63,64,86,87]$ are the most commonly utilized methods, each of which has its own advantages and disadvantages. Impregnation is the most convenient method to be scaled up, for manufacturing. However, nonhomogeneous distribution of the metal precursor is the biggest issue associated with the impregnation method, leading to metal agglomeration, one of the reasons which contribute to catalyst deactivation. On the contrary, it is easier for SG and CP to achieve homogeneous dispersion of active metal. However, the synthesis procedure of SG and CP is more complicated compared with that of impregnation, leading to poor reproducibility between various batches. Also, since most of the active metal atoms are embedded in the matrix of support, resulting in less exposure of active metal on the sample surface, SG and CP prepared samples are more stable but less active than those prepared by impregnation. In addition, several novel preparation protocols such as hydrothermal [96], solvothermal [97], and microemulsion [98] have been developed to control the sample particle size and morphology which have been shown to be highly relevant to catalytic activity. On the other hand, most of the newly developed methods mentioned involve the employment of organic solvents, which could be harmful to the surroundings. Although all the preparation techniques documented up to now supply abundant resources to start with, the establishment of an appropriate method balancing low cost, easy operation, and environmental benignancy is important to be researched.

\subsection{Cobalt based catalyst performance optimization}

A series of catalyst optimization efforts have been carried out in the past several years aiming to enhance the catalytic performance during BESR. Studies on cobalt-based catalysts supported on $\gamma-\mathrm{Al}_{2} \mathrm{O}_{3}, \mathrm{TiO}_{2}, \mathrm{ZrO}_{2}$ supports have indicated that ethanol conversion correlates closely with metal dispersion and hence, the metallic Co sites. Among the supports studied, zirconia is shown to provide the highest metal dispersion and the highest $\mathrm{H}_{2}$ yield. $\mathrm{H}_{2}$ yields as high as $92 \%$ (5.5 mol of $\mathrm{H}_{2}$ per mole of ethanol fed) are achieved over a $10 \% \mathrm{Co} / \mathrm{ZrO}_{2}$ catalyst at $550 \circ \mathrm{C}[69]$. 
Investigation of the evolution of the $\mathrm{Co}-\mathrm{ZrO}_{2}$ catalysts through different stages of the synthesis process showed that catalyst precursors start out with Co existing primarily in a nitrate phase and transforming into a $\mathrm{Co}_{3} \mathrm{O}_{4}$ phase in the fully calcined state. The reduction proceeds in two distinct steps as in $\mathrm{Co}_{3} \mathrm{O}_{4} \rightarrow \mathrm{CoO}$ and $\mathrm{CoO} \rightarrow \mathrm{Co}$. There is an optimum in each of the synthesis parameters, which gives the highest metallic Co surface area. The maximum in metallic Co area is often determined by a series of competing processes, such as transformation from a nitrate to an oxide phase and onset of crystallinity versus reaction with the support at higher calcination temperatures, reduction to metallic state versus sintering at higher reduction temperatures. The maximum in metallic Co area was seen to coincide with the maxima in both ethanol adsorption capacity and $\mathrm{H}_{2}$ yield in the BESR reaction, suggesting a strong correlation between metallic Co sites and BESR activity [99].

Although promising activity toward hydrogen production is observed over $\mathrm{Co} / \mathrm{ZrO}_{2}$, steady-state reaction experiments coupled with post-reaction characterization experiments showed significant deactivation of $\mathrm{Co} / \mathrm{ZrO}_{2}$ catalysts through deposition of carbon on the surface, mostly in the form of carbon fibers, the growth of which is catalyzed by the Co particles. The addition of ceria appears to improve the catalyst stability due to its high OSC and high oxygen mobility, allowing gasification/oxidation of deposited carbon as soon as it forms. Although Co sintering is also observed, especially over the $\mathrm{ZrO}_{2}$-supported catalysts, it does not appear to be the main mode of deactivation. The high oxygen mobility of the catalyst not only suppresses carbon deposition and helps maintain the active surface area, but it also allows delivery of oxygen to close proximity of ethoxy species, promoting complete oxidation of carbon to $\mathrm{CO}_{2}$, resulting in higher hydrogen yields. Overall, oxygen accessibility of the catalyst plays a significant role on catalytic performance during BESR [100].

the effect of impregnation medium on the activity of $\mathrm{Co} / \mathrm{CeO}_{2}$ catalysts was also systematically investigated under the environment of BESR. The significant catalytic performance improvement has been observed over ethanol impregnated $\mathrm{Co}-\mathrm{CeO}_{2}$ catalyst, especially at lower temperature $\left(300-400{ }^{\circ} \mathrm{C}\right)$, compared with its counterpart with aqueous impregnation. This promotion effect is considered to be closely related to the cobalt dispersion amelioration through cobalt particle segregation under the facilitation of surface carbon oxygenated species derived from ethanol impregnation. Moreover, even better catalytic performance is achieved using ethylene glycol as impregnation medium in our recent study, which might be closely related with the achievement of even smaller cobalt particle size due to its superior ability in preventing cobalt agglomeration probably originating from the presence of organic surface species [101].

In order to further improve the oxygen mobility within the catalyst, the effect of Ca doping on $\mathrm{CeO}_{2}$ support has been intensively studied. According to the observations obtained from the various characterization techniques employed, the introduction of calcium into the $\mathrm{CeO}_{2}$ lattice structure leads to the unit cell expansion and creation of oxygen vacancies due to lower oxidation state of $\mathrm{Ca}(2+)$ compared to $\mathrm{Ce}(4+)$, which facilitates the improvement of oxygen mobility. As a result, the catalytic performance has been significantly enhanced when $\mathrm{Ca}$ is present, leading to larger amount of final product formations $\left(\mathrm{H}_{2}\right.$ and $\left.\mathrm{CO}_{2}\right)$ from BESR reaction [102].

The influence of cobalt precursor on catalytic performance was also systematically investigated. Multiple cobalt precursors including inorganic salts and organometallic 
compounds were used to prepare $\mathrm{Co} / \mathrm{CeO}_{2}$ catalysts. The steady-state reaction experiments show much higher $\mathrm{H}_{2}$ yields and fewer side products over the catalysts prepared using organometallic precursors. Among these, the catalyst prepared using cobalt acetyl acetonate has the highest $\mathrm{H}_{2}$ yield, most favorable product distribution, and best stability. The superior performance is verified by the transient data. Characterization results point to an improved dispersion on the surface. It is possible that the organic ligands surrounding Co ions provide a spatial barrier effect, keeping the particles segregated and leading to better dispersion [103].

In the interest of figuring out the impact of catalyst preparation method on its performance during BESR, in addition to conventional Incipient Wetness Impregnation (IWI) method, solvothermal, hydrothermal, colloidal crystal templating, and reverse microemulsion methods have also been employed to prepare $\mathrm{CeO}_{2}$ support and $\mathrm{CeO}_{2}$ supported $\mathrm{Co}$ catalysts with various morphologies. All of the novel preparation techniques led to superior behavior in ethanol steam reforming reaction compared to IWI method. Among the catalysts studied, the one prepared with the reverse microemulsion technique showed the best performance, giving higher $\mathrm{H}_{2}$ yields at much higher space velocities. The catalyst also showed good stability, with no sign of deactivation when it was kept on-line at $400{ }^{\circ} \mathrm{C}$ for $120 \mathrm{~h}$. The superior performance is likely to be related to the improved cobalt dispersion, enhanced metal-support interaction and increased metal-support interphase facilitated by the reverse microemulsion technique. In addition, the hydrothermal method has also been employed to prepare the $\mathrm{Co} / \mathrm{CeO}_{2}$ catalyst. The $\mathrm{CeO}_{2}$ particles with various shapes and size distribution have been successfully achieved in our laboratories by controlling the parameters during preparation process. The morphological effect on the catalytic performance will be evaluated in the future [104].

\section{Reaction mechanism and kinetic studies}

As can be seen in Section 2.7, the reaction network which would possibly occur during BESR is fairly complicated and heavily dependent on the catalyst system employed. In order to obtain maximum amount of hydrogen out of ethanol used, the side reactions should be effectively suppressed, leading to the minimization of byproducts such as methane, carbon monoxide, acetaldehyde, acetone, acetic acid and so on. For controlling the reaction proceeding along the desired pathway which will give us the highest hydrogen yield, it is critical to gain a comprehensive understanding of the reaction mechanisms involved, which will in turn guide the rational design of catalyst system. There are two approaches we can follow to achieve our final goal, that is, theoretical and experimental directions. The theoretical approach (reaction mechanism study through computational chemistry) is still at its initial stage referring to the papers published in this area and will be covered in detail in Section 6. However, the experimental route has been widely adopted to study the catalytic behaviors present during BESR.

As an interfacial phenomenon, any heterogeneous catalytic reaction takes place involving three basic steps: reactants adsorption, surface reaction, and products desorption. To be a gas-solid reaction, catalytic BESR must embroil gas composition variation and catalyst surface evolution. Therefore, in order to attain a complete view of the reaction, systematical investigation should be performed on both gas and solid phases. Gas chromatography (GC) and mass spectrometer (MS) are the two popular instruments used to monitor the gas phase composition and fourier transform infared spectroscopy (FTIR) 
can detect the surface species and their evolutions during BESR. In addition, using other characterization techniques including nuclear magnetic resonance (NMR) and laser Raman spectroscopy (LRS) can provide an alternative way to get better insight into the reaction mechanisms.

Based on the results reported in the literature, the dehydrogenation and dehydration reactions are the two pathways ethanol can go through first, the choice of which depends on the catalysts charged. If the catalyst has high acidity (e.g., $\mathrm{Al}_{2} \mathrm{O}_{3}$ and $\mathrm{SiO}_{2}[105,106]$ supported samples), dehydration reaction is favored, resulting in the formation of $\mathrm{C}_{2} \mathrm{H}_{4}$, a precursor of coking through polymerization. If the catalyst presents basic features (e.g., $\mathrm{MgO}$ and $\mathrm{ZnO}[107,108]$ supported sample) instead, dehydrogenation reaction is preferred, leading to the production of acetaldehyde, an important reaction intermediate related to higher $\mathrm{H}_{2}$ yield. Acetaldehyde can then be decomposed into $\mathrm{CH}_{4}$ and $\mathrm{CO}$ [109] or undergoes steam reforming to generate $\mathrm{CO}$ and $\mathrm{H}_{2}$ relying on the catalyst employed. These single carbon containing products $\left(\mathrm{CH}_{4}\right.$ and $\left.\mathrm{CO}\right)$ can be further reformed to $\mathrm{CO}_{2}$ and $\mathrm{H}_{2}$ through methane steam reforming and water-gas shift reaction if sufficient water is supplied. Besides, two acetaldehyde molecules can react with each other to form acetone through aldol condensation reaction [35] or be oxidized to acetic acid [110]. Carbon can be formed at various stages from carbon-containing species via either cracking or Boudouard reaction [111].

Ethanol adsorption and subsequent surface reaction have been extensively studied over many different catalyst systems employing FTIR technique. Although the exact locations of the ethanol adsorption bands vary with catalysts tested, the identifications of surface species and its evolutions are well established. Ethanol can be adsorbed on the sample surface dissociatively and molecularly [112-114]. The ethoxide species is the result of ethanol dissociative adsorption. Then the surface acetate species is obtained from the oxidation of ethoxide by the lattice oxygen coming from the sample surface $[115,116]$. The acetate species can then experience C-C breakage leading to the formation of single carbon fragments. Whether these fragments will be released directly from the surface or undergo further oxidation to carbonate species is closely linked to the sufficiency of oxygen stored in the sample. The adequate oxygen supplies benefit the formation of carbonate species. Finally $\mathrm{CO}_{2}$ originates from the decomposition of carbonate species. However, compared with ethanol, water adsorption and its role in the subsequent surface reaction remain unclear for BESR. Therefore, the surface features need to be investigated during water adsorption and co-adsorption of water and ethanol.

${ }^{13} \mathrm{C}$ NMR technique has been applied into the study of ethanol adsorption behavior to track the evolution of carbon containing species over $\mathrm{Cu} / \mathrm{ZnO}$ [117]. Different oxygenate species have been identified after integrating with the results obtained from MS. Unfortunately, just 1-C was labeled in the ethanol molecule, in order to get a comprehensive picture of the surface species and its evolution after ethanol adsorption, 2$\mathrm{C}$, even $\mathrm{H}$ and $\mathrm{O}$ labeled ethanol is also worth being considered. A similar approach is also applicable for water adsorption and co-adsorption of ethanol and water by choosing suitable isotopic labeled elements.

Compared with the kinetic studies focused on the steam reforming over single carbon containing reactants such as methanol [118-122] and methane [123-127] (MSR) which have been investigated intensively for tens of years, the kinetic investigations performed over ethanol steam reforming (ESR) reaction are still in their burgeoning stage, which might be 
due to the relatively complicated reaction networks involved originating from the increase of carbon atom. However, the knowledge accumulated during the systematic explorations of the kinetic mechanisms occurring during MSR provides a valuable starting point for ESR researchers to expand upon. In recent years, based on the observations obtained from both gas phase and sample surface, several kinetic models have been proposed to simulate the mechanistic behaviors of various catalyst systems [128-132], which will facilitate better understanding of the reaction mechanisms. If the estimated values are in good consistency with the reported experimental results, the assumed reaction pathways and ratedetermining step (RDS) will uncover the actual reaction mechanisms to a certain level. Furthermore, the activation energy measured from this study provides the reference for molecular simulation. In addition, the outcomes from this kinetic analysis will benefit the reactor design which can promote mass and heat transfer during reaction.

Based on the TPD and DRIFTS results reported in [133], a possible reaction pathway for ethanol steam reforming over Co-based catalysts is proposed by our laboratories in Fig.6. In Scheme 1, the reactant molecules (EtOH and water) diffuse from gas phase to the surface of the catalyst. The ethanol molecules adsorb dissociatively on the Co sites, forming ethoxide species. Water, on the other hand, adsorbs on the support, forming hydroxyl groups. The first $\mathrm{H}$ abstracted from ethanol can either form $\mathrm{OH}$ groups with the surface oxygen species or combine with hydrogen from $\mathrm{H}_{2} \mathrm{O}$ and form $\mathrm{H}_{2}$ (Scheme 3). Ethoxide species move to the interface of metal and oxide support and be oxidized by an additional hydrogen abstraction forming aceteldehyde (Scheme 4). Acetaldehyde molecules may lead to the formation of acetone through an aldol-condensation type reaction and acetone molecules are observed only in the gas phase. Acetaldehyde species have a short surface residence time, converting readily to acetate species through further oxidation with surface oxygen or $\mathrm{OH}$ groups (Scheme 5). There are multiple routes for the acetate species once they are formed. In one of the routes, the metal may be involved in $\mathrm{C}-\mathrm{C}$ bond cleavage leading to the formation of single carbon species (Scheme 7), leading to the formation of $\mathrm{CH}_{4}$. The carbon-oxygen surface species may desorb or further oxidize to give carbonate species, especially on supports with high oxygen storage capacity (Scheme 8), which can desorb as $\mathrm{CO}_{2}$ (Scheme 9). In a second route, especially, if oxygen accessibility is high, the $\mathrm{CH}_{3}$ fragment will undergo oxidation through $\mathrm{H}$ subtraction and $\mathrm{O}$ addition (Scheme 10) to form formate, possibly through a formaldehyde intermediate (Scheme 11), and carbonate (Scheme 12). The catalyst surface is then regenerated through $\mathrm{CO}_{2}$ desorption (Scheme 13) and ready for the next catalysis cycle regardless of the route followed.

If the surface is highly acidic, ethanol dehydration may dominate the reaction pathway and result in the formation of $\mathrm{H}_{2} \mathrm{O}$ and $\mathrm{C}_{2} \mathrm{H}_{4}$ which is the major precursor to coke due to polymerization, as described in Scheme 2 and 6 . If the oxygen mobility in the catalyst is not high enough, the acetate species may remain on the surface and lead to coke formation, as reported earlier [34, 134].

Briefly speaking, dissociative adsorption of ethanol and water leads to ethoxide species and hydroxyl groups, respectively. The active metal catalyzes the $\mathrm{C}-\mathrm{C}$ bond cleavage and formation of single carbon species. BESR reaction could happen at the interface of the active metal and the oxide support, which could participate by providing oxygen from the lattice to facilitate the oxidation of carbon species. The resulting oxygen vacancies can be filled by the oxygen in the hydroxyl species formed from water adsorption. Therefore, it is necessary to have rapid oxygen delivery mechanism throughout the oxide support to prevent carbon deposition on the surface due to deficient oxidation of carbon species. High metal dispersion 


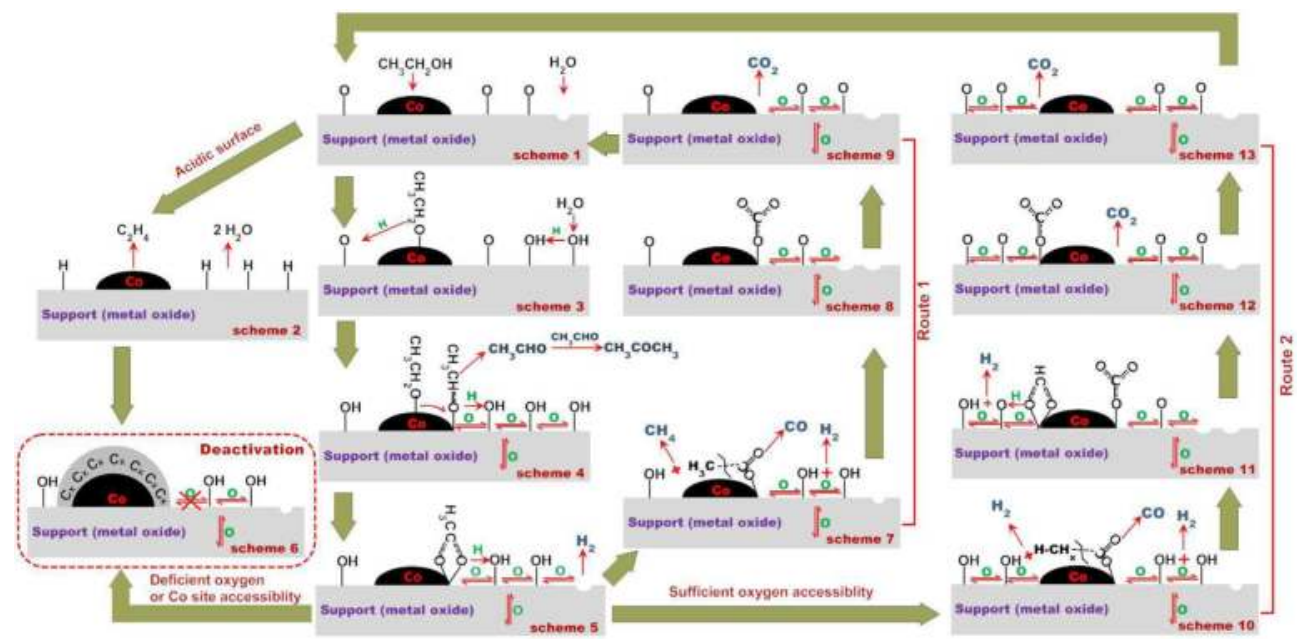

Fig. 6. Proposed Reaction Mechanism for Ethanol Steam Reforming over supported Co catalysts

will favor the ethanol adsorption and formation of more accessible metal/oxide interfaces as well as C-C cleavage. High oxygen storage capability and mobility will facilitate the oxygen delivery through the support and suppress coke deposition. The Co-based systems that incorporate oxides with high oxygen storage and oxygen mobility could deliver the required characteristics needed for active and stable BESR catalysts.

\section{Computational approaches}

Compared to significant amount of experimental efforts spent on catalytic BESR for surface reaction mechansim investigation, computational approach at molecular level still remains barely untouched in the past several decades probably due to its extreme complicacy and limited computation resources. However, recent years have witnessed the rapid development of computational technology, making the reaction simulation at catalyst surface technically feasible. For simplifying simulation work, many publications have purely focused on the ethanol or water alone adsorption and associated decomposition on single metal clusters [135-139].

Various methodologies have been developed to reasonably represent catalyst surface for obtaining more accurate simulation results. The slab geometry in contrast to cluster model is widely adopted to model the catalyst surface with certain thickness. In addition to the top atomic layer, several successive layers below are also included to simulate the bulk effect on the surface layer. The surface layer is thereafter allowed to be reconstructed in response to the constraint from bulk layers. Usually, a vacuum region with certain length is created right above the top layer of the slab model to prevent the interaction of adsorbed molecules with its periodic images [140]. The choice of supercell size comes from the compromise between computation accuracy and computation time span. "Nudged Elastic Band (NEB)" method [141, 142] is proven by many papers to be effective in transition state and associated energy barrier estimation and very useful in minimum energy pathway determination especially for complex chemical reactions. Most of recently published computational results 
are based on the self-consistent periodic density functional theory (DFT) calculation, which is more accurate than other commonly used computational methods such as ab initio, semiempirical, and empirical methods.

According to the published papers, although there are some disagreements on the ethanol decomposition on model catalyst surface, the proposed pathways can still be generally classified into two routes. One is $\mathrm{CH}_{3} \mathrm{CH}_{2} \mathrm{OH} \rightarrow \mathrm{CH}_{3} \mathrm{CH}_{2} \mathrm{O}_{(\mathrm{a})} \rightarrow \mathrm{CH}_{2} \mathrm{CH}_{2} \mathrm{O}_{(\mathrm{a})} \rightarrow \mathrm{CH}_{2} \mathrm{CHO}_{(\text {a) }}$ $\rightarrow \mathrm{CH}_{2} \mathrm{CO}_{(\mathrm{a})} \rightarrow \mathrm{CH}_{2(\mathrm{a})}+\mathrm{CO}_{(\mathrm{a})}+4 \mathrm{H}_{(\mathrm{a})} \rightarrow \mathrm{CH}_{4(\mathrm{~g})}+\mathrm{CO}_{(\mathrm{g})}+\mathrm{H}_{2(\mathrm{~g})}$. In this route, ethanol molecule first prefers to adsorb at atop sites and binds to the surface through the oxygen atom after $\mathrm{O}-\mathrm{H}$ bond cleavage, followed by a six-membered ring of an oxametallacyclic compound formation through the elimination of the hydrogen atom attached to the $\beta$-carbon. This sixmembered ring is usually located at the interface of active metal and support, creating a bridge between them. The ethanol decomposition process then continues with two consecutive eliminations of hydrogen atom attached to a-carbon. Scission of C-C bond then occurs under the facilitation of active metal, resulting in the formations of a series of adsorbates which subsequently desorb from substrate at elevated temperature to yield final gas products such as $\mathrm{CH}_{4}, \mathrm{CO}$, and $\mathrm{H}_{2}$ [142-144]. The other suggested route follows the track of $\mathrm{CH}_{3} \mathrm{CH}_{2} \mathrm{OH} \rightarrow \mathrm{CH}_{3} \mathrm{CHOH}_{(\mathrm{a})} \rightarrow \mathrm{CH}_{3} \mathrm{CHO}_{(\mathrm{a})} \rightarrow \mathrm{CH}_{3} \mathrm{CO}_{(\mathrm{a})} \rightarrow \mathrm{CH}_{2} \mathrm{CO}_{(\mathrm{a})} \rightarrow \mathrm{CHCO}_{(\mathrm{a})} \rightarrow$ $\mathrm{CH}_{(\mathrm{a})}+\mathrm{CO}_{(\mathrm{a})} \rightarrow \mathrm{CH}_{4(\mathrm{~g})}+\mathrm{CO}_{(\mathrm{g})}+\mathrm{H}_{2(\mathrm{~g})}+\mathrm{C}_{(\mathrm{s})}[145]$.

Unlike ethanol decomposition, water dissociation completes only in two steps (i.e., $\mathrm{H}_{2} \mathrm{O} \rightarrow$ $\left.\mathrm{H}_{(\mathrm{a})}+\mathrm{OH}_{(\mathrm{a})} \rightarrow 2 \mathrm{H}_{(\mathrm{a})}+\mathrm{O}_{(\mathrm{a})}\right)$, which is obviously due to its rather simple formulation. Compared to the second $\mathrm{O}-\mathrm{H}$ bond breakage, the first one can take place with much lower activation energy [146]. Therefore, it can be easily predicted that hydroxyl group will have much higher chance to participate in BESR for ethanol oxidation than $\mathrm{O}^{*}$ after water complete dissociation.

After a careful literature review, it is worth noting that the role of catalyst support and coadsorption of ethanol and water are barely considered, which is probably attributed to its awful computational complicacy. In order to give a clear picture of what is really happening on catalyst surface during BESR and provide a theoretical support to our experimental observations and proposed reaction mechanism, we launched a computational task in collaboration with the Chemistry Department at Ohio State University. We employed planewave periodic DFT method implemented in the Vienna ab initio simulation program (VASP) to investigate the ethanol steam reforming reactions [147-149]. The projector augmented wave (PAW) method [150, 151], combined with a plane-wave basis set, was utilized to describe the core and valence electrons. The generalized gradient approximation (GGA) [152] of Perdew and Wang (PW91) [153] was applied for the exchange-correlation functional. The convergence of the plane-wave expansion was obtained with moderate truncation energy of $500 \mathrm{eV}$, while the electronic relaxation was converged to a tolerance of $1 \times 10^{-4} \mathrm{eV}$. The Monkhorst-Pack grid [154] served in the generation of the k-points, and a (4 $\times 4 \times 1$ ) k-point grid was used for Brillouin zone sampling for surface calculations. Spin polarization was applied in all calculations.

The relaxed bulk structure of $\mathrm{CeO}_{2}$ with a lattice parameter of $5.46 \AA$ was used to construct the slab model. The $\mathrm{CeO}_{2}(111)$ and $\mathrm{Co} / \mathrm{CeO}_{2}$ (111) surfaces were modeled as $2 \times 1$ super cells. A three molecular $\mathrm{CeO}_{2}$ thick slab model was constructed, thus nine atomic layers in total. The super cell has dimensions: $\mathrm{a}=7.72 \AA, \mathrm{b}=6.69 \AA$, and $\mathrm{c}=23.88 \AA$, and a $16 \AA$ thick vacuum region is included to ensure that there is no interaction between the surface adsorbates of one layer and the next slab. To optimize the surface structure, the top three atomic layers of the slab with the adsorbates were allowed to relax. The bottom six atomic 
layers were fixed at the bulk positions of ceria. The NEB method [155-157] was employed to locate the transition states of various reactions over the catalyst surface. After numerical differentiation, each transition state was confirmed to have a single imaginary vibrational frequency.

Ethanol decomposition via steam reforming reaction was computationally studied on the $\mathrm{CeO}_{2}(111)$ and $\mathrm{Co} / \mathrm{CeO}_{2}(111)$ surfaces. From our results, the most likely reaction pathway is described below. The decomposition of ethanol starts with the breaking of the $\mathrm{O}-\mathrm{H}$ bond on the catalyst surface. The produced ethoxide unit prefers to be adsorbed on the catalyst surface by the $\mathrm{O}_{\mathrm{e}} \cdots \mathrm{Co}$ interaction. With the assistance of a surface-bound hydroxyl moiety, derived from water dissociation, the $\mathrm{C}_{\alpha}-\mathrm{H}$ bond breaking of the ethoxide unit could proceed to yield the thermodynamically stable product (adsorbed acetaldehyde and hydrogen atom). The surface-bound hydroxyl group could act as a better hydrogen acceptor to assist the $\mathrm{C}_{\alpha}-$ $\mathrm{H}$ bond-breaking reaction as compared to the surface oxygen atom of ceria. In the subsequent step, the surface-bound hydroxyl addition to acetaldehyde produces the hydroxyl adduct, $\mathrm{CH}_{3} \mathrm{CH}(\mathrm{O})(\mathrm{OH})$, as an intermediate. This $\mathrm{CH}_{3} \mathrm{CH}(\mathrm{O})(\mathrm{OH})$ intermediate further undergoes the loss of $\mathrm{H}$ from the $\mathrm{C}_{\alpha}$ position to generate acetic acid. Acetic acid can then lose the acidic hydrogen from the hydroxyl unit, yielding an adsorbed acetate and hydrogen. The acetate could be further converted to the $\mathrm{CH}_{2}(\mathrm{OH}) \mathrm{COO}$ intermediate via Hatom abstraction and subsequent surface-bound hydroxyl addition reactions. As suggested by the calculations, the $\mathrm{C}_{\alpha}-\mathrm{C}_{\beta}$ bond rupture from the chemisorbed $\mathrm{CH}_{2}(\mathrm{O}) \mathrm{COO}$ intermediate generates formaldehyde and $\mathrm{CO}_{2}$. Similar to acetaldehyde, the generated formaldehyde could react with a surface-bound hydroxyl group to produce the $\mathrm{HCH}(\mathrm{O})(\mathrm{OH})$ adduct that subsequently undergoes a $\mathrm{H}$-atom abstraction reaction to yield formic acid. Then, formic acid loses the acidic hydrogen of the hydroxyl unit to generate surface-bound formate. Finally, formate could be converted to $\mathrm{CO}_{2}$. Throughout the favorable reaction pathway from ethanol to $\mathrm{CO}_{2}$, one of the most energetically costly steps on the potential energy surface is the $\mathrm{C}_{\beta}-\mathrm{H}$ bond-breaking step of acetate for ethanol decomposition with the participation of surface-bound hydroxyl groups on the $\mathrm{Co} / \mathrm{CeO}_{2}(111)$ surface.

Our modeling indicates that surface-bound hydroxyl groups, which is formed from water dissociation, plays two critical roles in the ethanol steam reforming reaction. The first is to assist the hydrogen-abstraction reactions from carbon atoms. The second is their involvement in addition reactions to form the $\mathrm{C}=\mathrm{O}$ or $\mathrm{C}=\mathrm{C}$ double bond intermediates. Thus, a catalyst on which water could more effectively dissociate to form surface-bound hydroxyl and hydrogen might be a potentially better catalyst for steam reforming reactions. On the $\mathrm{Co} / \mathrm{CeO}_{2}(111)$ surface, our computational work elucidates the formation of acetaldehyde and acetate intermediates and is consistent with extant experimental observations [133]. The present computational studies do not account for the generation of acetone, carbon monoxide, and methane, which are byproducts observed in experimental studies. A model that includes larger Co particles with some surface-bound hydroxyl groups would be more realistic and may account for the formation of other byproducts.

\section{Economic considerations}

Although recent years have witnessed an increasing number of studies in the literature on BESR reaction, the commercialization of a BESR process for hydrogen production still faces many obstacles before it can become a reality. The major obstacle is the cost associated with 
the process. While the cost of the catalyst, which is usually precious-metal based, can be an inhibitive factor, a detailed analysis of the economics involved in the process and an understanding of the contribution of many cost factors are still lacking.

An economic analysis model based on the cost structures in the United States was thereafter developed by our laboratories based on a process for hydrogen production from bio-ethanol steam reforming. The process includes upstream feedstock considerations as well as downstream hydrogen purification strategies and is analyzed for two different capacity levels, namely a central production scheme (150,000 $\mathrm{kg} \mathrm{H}_{2} /$ day) and a distributed (forecourt) production scheme $\left(1,500 \mathrm{~kg} \mathrm{H}_{2} /\right.$ day). The analysis was based on several assumptions and input parameters provided by the US Department of Energy and involved sensitivity analyses of several input parameters and their effects on the hydrogen selling price.

The detailed methodologies for performing economic analysis and associated results and discussions can be found in our recent publication [158]. Here we just give a brief summary of what we have obtained from this study. The hydrogen selling price is determined to be $\$ 2.69 / \mathrm{kg} \mathrm{H}_{2}$ at central hydrogen production scale. According to cost breakdown analysis, ethanol feedstock contributes almost $70 \%$ of the total cost. Nevertheless, this technique is still economically competitive with other commonly used hydrogen generation technologies at same production scale such as methane steam reforming $\left(\$ 1.5 / \mathrm{kg} \mathrm{H}_{2}\right)$, and biomass gasification $\left(\$ 1.77 / \mathrm{kg} \mathrm{H}_{2}\right)$. When the production scale is downsized to forecourt level, the hydrogen selling price is significantly increased up to $\$ 4.27 / \mathrm{kg} \mathrm{H}_{2}$, which is mainly attributed to the significant increase of capital cost contribution. A series of sensitivity analyses have been performed in order to determine the most significant factor influencing the final hydrogen selling price. From the analyses, hydrogen yield has a major effect on the estimated selling price through variation on ethanol feedstock cost contribution, which is reasonable since higher yield would require less feedstock to produce the same amount of hydrogen. Feed dilution is another important impact on hydrogen selling price, particularly at higher dilution percentage. The exponential escalation of hydrogen selling price is clearly observed when the dilution percentage is higher than $50 \%$. Higher dilution percentage means that larger amount of gas should be processed to get the same amount of hydrogen. The effect of molar ratio of ethanol to water variation on hydrogen selling price has also been evaluated. As expected, hydrogen selling price is increased along with increasing molar ratio of water to ethanol, because larger amount of water is required to be evaporated to get the same amount of hydrogen, resulting in the capital and operation cost increase. However, another factor that is not reflected in this analysis is the fact that excess water (i.e., larger water-to-ethanol ratios) would inhibit coking on the surface and extend the active catalyst life time. So, choosing a higher water input may have additional advantages not captured by this analysis. Finally, the effect of catalyst cost and associated performance on hydrogen selling price has also been intensively explored. The estimations indicate the significance of using transition metal based catalyst for hydrogen production from BESR. If noble metal based catalyst is used instead, the hydrogen selling price will jump up to $\$ 22.34 / \mathrm{kg} \mathrm{H}_{2}$ from $\$ 4.27 / \mathrm{kg} \mathrm{H}_{2}$ where transition metal (e.g., Co) based catalyst is employed assuming that their catalytic performance is comparable. In order to get the same hydrogen selling price, the noble metal based catalyst has to either be operated under gas hourly space velocity 100 times higher or has lifetime 100 times longer than those of transition metal based catalyst, which is almost impossible from a realistic viewpoint. 


\section{Future development directions}

The technical advantage of ethanol steam reforming over direct ethanol combustion for power generation is the improvement of thermal efficiency through hydrogen production exclusively used for fuel cell. In addition to stationary electricity generation, fuel cell is also designed for powering portable devices such as automobile. It is unsafe to travel around with compressed hydrogen tank on board. Therefore, there is a necessity for on-board steam reformer development where liquid ethanol rather than compressed hydrogen gas is fed into the storage tank. In order to get better mileage per gallon ethanol fed, the very important requirement of on-board steam reformer development is its light weight, which generates great demands on size reduction of on-board reformer. To fulfill the miniaturization and compactness requirements, various types of micro-structured reactors have been developed in recent years, which is typically composed of stacks of channeled blocks. Each micro-channel coated with active catalyst acts as the steam reformer for hydrogen production. Partial ethanol is combusted in the other side of the channel to supply heat required for reforming. Such design provides many technical advantages including rapid mass and heat transport due to large surface area to volume ratios, lower pressure drop, good structural and thermal stability, and precise control of reaction conditions leading to higher hydrogen yield $[159,160]$. The main challenges faced by this technique before it becomes final commercialization are system integration, reactor fabrication process, and catalyst regeneration or replacement.

Combinatorial method originally developed for drug discovery has been introduced into the catalyst discovery field in the last decade to accelerate the catalyst screening process. By using this high-throughput approach, large and diverse libraries of inorganic materials can be prepared, processed, and tested simultaneously under the same reaction conditions for quickly obtaining potential candidates with desirable catalytic performance, which is beneficial for significant reduction of time and money spent on catalyst development [161, 162]. However, the relatively complicated algorithms for testing matrix determination, expensive testing instrument, and representability of the screening results should be better handled before it can be widely accepted as a standard catalyst development strategy.

The influence of external field (e.g., electric and magnetic field) on catalytic performance during BESR could be another interesting area to study. Because any chemical reaction involves electron transfer and rearrangement facilitated by the addition of catalyst, the application of external field which can exert impact on electron movement is expected to have influence on catalytic reactivity. Such effect has been recently evidenced by L. Yuan, et al. that hydrogen yield and selectivity were significantly enhanced when an AC current passed through $\mathrm{Ni} / \mathrm{Al}_{2} \mathrm{O}_{3}$ catalyst [163].

According to LeChatelier's Principle, referring to Reaction (1), continuous removal $\mathrm{CO}_{2}$ from product stream can shift the reaction equilibrium toward products side, leading to the improvement of hydrogen production. Based on literature review, there are mainly two methods for $\mathrm{CO}_{2}$ in-situ removal: addition of $\mathrm{CO}_{2}$ sorbent and $\mathrm{CO}_{2}$ selective membrane. The $\mathrm{CO}_{2}$ sorbent used for this purpose has to be regenerated at temperature higher than reaction temperature for reuse. For doing so, the high temperature $\mathrm{CO}_{2}$ sorbent has to be circulated between reactor and regenerator [164]. The $\mathrm{CO}_{2}$ sorbent is usually regenerated under the hot air environment and has good resistance to high temperature and attrition. According to literature reporting, $\mathrm{CaO}$ and lithium silicate are among the most commonly used $\mathrm{CO}_{2}$ sorbents for hydrogen production. For $\mathrm{CO}_{2}$ selective membrane, $\mathrm{CO}_{2}$ is either 
rejected by the membrane and stays in the retentate side, or diffuses through the membrane and swept out as permeate. In order to in-situ remove $\mathrm{CO}_{2}$ or perform hydrogen purification within the reformer, various types of membrane reactors have been developed in recent years to obtain hydrogen rich gas stream. Moreover, catalytic membrane reactor has also been invented to perform water-gas shift (WGS) and separation simultaneously through applying certain catalyst onto the membrane surface, among which Pdimpregnated membrane is the most reported one for getting purfied hydrogen product [165, 166]. Nevertheless, many technical problems including cost reduction, selectivity and permeation efficiency improvement, and rigidity enhancement have to be solved before it becomes economically attractive.

The high cost of ethanol feedstock for steam reforming mainly comes from the downstream distillation and purification steps of the crude ethanol obtained from fermentation. If the crude ethanol can be directly used as the feedstock for hydrogen production from BESR, the large amount of energy wasted during distillation for water and other impurities removal can be eliminated, leading to the significant cost reduction of ethanol feedstock and in turn hydrogen produced from BESR. In addition, other oxygenated hydrocarbons contained in the fermentation broth can also be steam reformed to generate extra $7 \%$ hydrogen if crude ethanol is employed compared to steam reforming of pure ethanol. Although this approach sounds promising for final commercialization of BESR technique, the challenge still remains at the catalyst's tolerance to the impurities present in the crude ethanol solution. According to related publications, several researchers have conducted such study to evaluate the impact of impurities on catalytic performance toward hydrogen production. A. Akande and his coworkers investigated the influence of crude ethanol simulated through adding small amount of lactic acid, glycerol, and maltose to ethanol aqueous solution on the catalytic performance of $\mathrm{Ni} / \mathrm{Al}_{2} \mathrm{O}_{3}[128,167]$. Initial catalyst deactivation was observed followed by stable run within 12 hours test. Similar study has also been performed by our group over $\mathrm{Co} / \mathrm{CeO}_{2} . \sim 90 \%$ hydrogen yield is achieved and well maintained within 100 hours run. A more systematic research has been recently implemented by $\mathrm{A}$. Valant, et al. over $\mathrm{Rh} / \mathrm{MgAl}_{2} \mathrm{O}_{4}$ [168]. More oxygenated hydrocarbons including esters, aldehydes, amine, acetic acid, methanol, and linear or branched alchols have been tested for its influences on catalytic performance of BESR. Catalyst deactivation is observed for certain impurity additions. Through catalyst modification, much better stability has been achieved using Rh$\mathrm{Ni} / \mathrm{Y}-\mathrm{Al}_{2} \mathrm{O}_{3}$.

Although high pressure operation will result in inhibition of hydrogen production, as predicted thermodynamically referring to Section 2.7, it is still worth investigating, because high pressure operation will significantly lower down the hydrogen compression cost for storage and transporation. In order to compensate the hydrogen production loss, hydrogen selective membrane reactor has been recently proposed in combination with high pressure operation by Argonne National Laboratory [169]. By doing so, the formed hydrogen can be continuously removed leading to the thermodynamic equilibrium shift toward hydrogen production.

\section{Acknowledgment}

We gratefully acknowledge funding from the U.S. Department of Energy through grant DEFG36-05GO15033. The Ohio Supercomputer Center (OSC) is also acknowledged for generous computational support of this research. 


\section{References}

[1] A National Vision of America's Transition to A Hydrogen Economy - To 2030 and Beyond; U.S. Department of Energy (DOE): Washington, D.C, 2002

[2] Idriss, H. (2004). Ethanol Reactions over the Surfaces of Noble Metal/Cerium Oxide Catalysts. Platinum Metals Review, Vol.48, No.3, (July 2004), pp. 105-115, ISSN 00321400

[3] Das, D., Veziroğlu, T.N. (2001). Hydrogen Production by Biological Processes: A Survey of Literature. International Journal of Hydrogen Energy, Vol.26, No.1, (January 2001), pp. 13-28, ISSN 0360-3199

[4] Nath, K., Das, D. (2004). Improvement of Fermentative Hydrogen Production: Various Approaches. Applied Microbiology and Biotechnology, Vol.65, No.5, (July 2004), pp. 520-529, ISSN 0175-7598

[5] Hallenbeck, P.C., Benemann, J.R. (2002). Biological Hydrogen Production; Fundamentals and limiting processes. International Journal of Hydrogen Energy, Vol.27, No.11-12, (November-December 2002), pp. 1185-1193, ISSN 0360-3199

[6] Hwang, M.H., Jang, N.J., Hyun, S.H., Kim, I.S. (2004). Anaerobic Bio-Hydrogen Production from Ethanol Fermentation: the Role of $\mathrm{pH}$. Journal of Biotechnology, Vol.111, No.3, (August 2004), pp. 297-309, ISSN 0168-1656

[7] Maness, P.C., Weaver, P.F. (1999). Biological $\mathrm{H}_{2}$ from Fuel Gases and from $\mathrm{H}_{2} \mathrm{O}$. Proceedings of the 1999 US DOE Hydrogen Program Review

[8] Nada, A.A., Barakat, M.H., Hamed, H.A., Mohamed, N.R., Veziroglu, T.N. (2005). Studies on the Photocatalytic Hydrogen Production Using Suspended Modified $\mathrm{TiO}_{2}$ Photocatalysts. International Journal of Hydrogen Energy, Vol.30, No.7, (July 2005), pp. 687-691, ISSN 0360-3199

[9] Vorontsov, A.V., Dubovitskaya, V.P. (2004). Selectivity of Photocatalytic Oxidation of Gaseous Ethanol over Pure and Modified $\mathrm{TiO}_{2}$. Journal of Catalysis, Vol.221, No.1, (January 2004), pp.102-109, ISSN 0021-9517

[10] Yu, Z., Chuang, S. (2007). In-situ IR Study of Adsorbed Species and Photogenerated Electrons During Photocatalytic Oxidation of Ethanol on $\mathrm{TiO}_{2}$. Journal of Catalysis, Vol.246, No.1, (February 2007), pp.118-126, ISSN 0021-9517

[11] Kasata, T., Kawai, T. (1981). Heterogeneous Photocatalytic Production of Hydrogen and Methane from Ethanol and Water. Chemical Physics Letters, Vol.80, No.2, (June 1981), pp. 341-344, ISSN 0009-2614

[12] Bamwenda, G.R., Tsubota, S., Nakamura, T., Haruta, M. (1995). Photoassisted Hydrogen Production from A Water-Ethanol Solution: A Comparison of Activities of $\mathrm{Au}-\mathrm{TiO}_{2}$ and $\mathrm{Pt}-\mathrm{TiO}_{2}$. Journal of Photochemistry and Photobiology A: Chemistry, Vol.89, No.2, (July 1995), pp. 177-189, ISSN 1010-6030

[13] Klosek, S., Raftery, D. (2001). Visible Light Driven V-Doped $\mathrm{TiO}_{2}$ Photocatalyst and Its Photooxidation of Ethanol. Journal of Physical Chemistry B, Vol.105, No.14, (March 2001), pp. 2815-2819, ISSN 1520-6106

[14] Yang, Y.Z., Chang, C.H., Idriss, H. (2006). Photo-Catalytic Production of Hydrogen from Ethanol over $\mathrm{M} / \mathrm{TiO}_{2}$ Catalysts $(\mathrm{M}=\mathrm{Pd}, \mathrm{Pt}$ or $\mathrm{Rh})$. Applied Catalysis $B$ : Environmental, Vol.67, No.3-4, (October 2006), pp. 217-222, ISSN 0926-3373 
[15] Strataki, N., Antoniadou, M., Dracopoulos, V., Lianos, P. (2010). Visible-Light Photocatalytic Hydrogen Production from Ethanol-Water Mixtures Using A PtCdS- $\mathrm{TiO}_{2}$ Photocatalyst. Catalysis Today, Vol.151, No.1-2, (April 2010), pp. 53-57, ISSN 0920-5861

[16] Wang, Y., Zhang, Z., Zhu, Y., Li, Z., Vajtai, R., Ci, L., Ajayan, P.M. (2008). Nanostructured $\mathrm{VO}_{2}$ Photocatalysts for Hydrogen Production. ACS Nano, Vol.2, No.7, (July 2008), pp. 1492-1496, ISSN 1936-0851

[17] Baeck, S., Choi, K., Jaramillo, T., Stucky, G., McFarland, E. (2003). Enhancement of Photocatalytic and Electrochromic Properties of Electrochemically Fabricated Mesoporous $\mathrm{WO}_{3}$ Thin Films. Advanced Materials, Vol. 15, No.15, (August 2003), pp. 1269-1273, ISSN 1521-4095

[18] Fu, X., Leung, D., Wang, X., Xue, W., Fu, X. (2011). Photocatalytic Reforming of Ethanol to $\mathrm{H}_{2}$ and $\mathrm{CH}_{4}$ over $\mathrm{ZnSn}(\mathrm{OH})_{6}$ nanotubes. International Journal of Hydrogen Energy, Vol.36, No.2, (January 2011), pp. 1524-1530, ISSN 0360-3199

[19] Mizukoshi, Y., Makise, Y., Shuto, T., Hu, J., Tominaga, A., Shironita, S., Tanabe, S. (2007). Immobilization of Noble Metal Nanoparticles on the Surface of $\mathrm{TiO}_{2}$ by the Sonochemical Method: Photocatalytic Production of Hydrogen from An Aqueous Solution of Ethanol. Ultrasonics Sonochemistry, Vol.14, No.3, (March 2007), pp. 387392, ISSN 1350-4177

[20] Davda, R.R., Shabaker, J.W., Huber, G.W., Cortright, R.D., Dumesic, J.A. (2005). A Review of Catalytic Issues and Process Conditions for Renewable Hydrogen and Alkanes by Aqueous-Phase Reforming of oxygenated Hydrocarbons over Supported Metal Catalysts. Applied Catalysis B: Environmental, Vol.56, No.1-2, (March 2005), pp. 171-186, ISSN 0926-3373

[21] Tokarev, A.V., Kirilin, A.V., Murzina, E.V., Eränen, K., Kustov, L.M., Murzin, D.Y., Mikkola, J.P. (2010). The Role of Bio-Ethanol in Aqueous Phase Reforming to Sustainable Hydrogen. International Journal of Hydrogen Energy, Vol.35, No.22, (November 2010), pp. 12642-12649, ISSN 0360-3199

[22] Wang, W., Wang, Y. (2009). Dry Reforming of Ethanol for Hydrogen Production: Thermodynamic Investigation. International Journal of Hydrogen Energy, Vol.34, No.13, (July 2009), pp. 5382-5389, ISSN 0360-3199

[23] Hu, X., Lu, G. (2009). Syngas Production by $\mathrm{CO}_{2}$ Reforming of Ethanol over $\mathrm{Ni} / \mathrm{Al}_{2} \mathrm{O}_{3}$ Catalyst. Catalysis Communications, Vol.10, No.13, (July 2009), pp. 1633-1637, ISSN 1566-7367

[24] Silva, A., Souza, K., Jacobs, G., Graham, U., Davis, B., Mattos, L., Noronha, F. (2011). Steam and $\mathrm{CO}_{2}$ Reforming of Ethanol over Rh/ $\mathrm{CeO}_{2}$ Catalyst. Applied Catalysis B: Environmental, Vol.102, No.1-2, (February 2011), pp. 94-109, ISSN 0926-3373

[25] Jankhah, S., Abatzoglou, N., Gitzhofer, F. (2008). Thermal and Catalytic Dry Reforming and Cracking of Ethanol for Hydrogen and Carbon Nanofilaments' Production. International Journal of Hydrogen Energy, Vol.33, No.18, (September 2008), pp. 47694779, ISSN 0360-3199

[26] Oliveira-Vigier, K.D., Abatzoglou, N., Gitzhofer, F. (2005). Dry-Reforming of Ethanol in the Presence of A 316 Stainless Steel Catalyst. The Canadian Journal of Chemical Engineering, Vol.83, No.6, (December 2005), pp. 978-984, ISSN 1939-019X 
[27] Petitpas, G., Rollier, J.D., Darmon, A., Gonzalez-Aguilar, J., Metkemeijer, R., Fulcheri, L. (2007). A Comparative Study of Non-Thermal Plasma Assisted Reforming Technologies. International Journal of Hydrogen Energy, Vol.32, No.14, (September 2007), pp. 2848-2867, ISSN 0360-3199

[28] Aubry, O., Met, C., Khacef, A., Cormier, J.M. (2005). On the Use of A Non-Thermal Plasma Reactor for Ethanol Steam Reforming. Chemical Engineering Journal, Vol.106, No.3., (February 2005), pp. 241-247, ISSN 1385-8947

[29] Wang, W., Wang, Z., Ding, Y., Xi, J., Lu, G. (2002). Partial Oxidation of Ethanol to Hydrogen over Ni-Fe Catalysts. Catalysis Letters, Vol.81, No.1-2, (January 2002), pp. 63-68, ISSN 1011-372X

[30] Mattos, L.V., Noronha, F.B. (2005). Hydrogen production for fuel cell applications by ethanol partial oxidation on $\mathrm{Pt} / \mathrm{CeO}_{2}$ catalysts: the effect of the reaction conditions and reaction mechanism. Journal of Catalysis, Vol.233, No.2, (July 2005), pp.453-463, ISSN 0021-9517

[31] Hsu, S., Bi, J., Wang, W., Yeh, C., Wang, C. (2008). Low Temperature Partial Oxidation of Ethanol over Supported Platinum Catalysts for Hydrogen Production. International Journal of Hydrogen Energy, Vol.33, No.2, (January 2008), pp. 693-699, ISSN 0360-3199

[32] Vaidya, P.D., Rodrigues, A.E. (2006). Insight into Steam Reforming of Ethanol to Produce Hydrogen for Fuel Cells. Chemical Engineering Journal, Vol.117, No.1., (March 2006), pp. 39-49, ISSN 1385-8947

[33] Ni, M., Leung, D., Leung, M. (2007). A Review on Reforming Bio-Ethanol for Hydrogen Production. International Journal of Hydrogen Energy, Vol.32, No.15, (October 2007), pp. 3238-3247, ISSN 0360-3199

[34] Erdóhelyi, A., Raskó, J., Kecskés, T., Tóth, M., Dőmők, M., Baán, K. (2006). Hydrogen Formation in Ethanol Steam Reforming on Supported Noble Metal Catalysts. Catalysis Today, Vol.116, No.3, (August 2006), pp. 367-376, ISSN 0920-5861

[35] Liguras, D.K., Kondarides, D.I., Verykios, X.E. (2003). Production of Hydrogen for Fuel Cells by Steam Reforming of Ethanol over Supported Noble Metal Catalysts. Applied Catalysis B: Environmental, Vol.43, No.4, (July 2003), pp. 345-354, ISSN 09263373

[36] Koh, A., Leong, W.K., Chen, L., Ang, T.P., Lin, J. (2008). Highly Efficient Ruthenium and Ruthenium-Platinum Cluster-Derived Nanocatalysts for Hydrogen Production via Ethanol Steam Reforming. Catalysis Communications, Vol.9, No.1, (January 2008), pp. 170-175, ISSN 1566-7367

[37] Bi, J., Hong, Y., Lee, C., Yeh, C., Wa, C. (2007). Novel Zirconia-Supported Catalysts for Low-Temperature Oxidative Steam Reforming of Ethanol. Catalysis Today, Vol.129, No.3-4, (December 2007), pp. 322-329, ISSN 0920-5861

[38] Breen, J.P., Burch, R., Coleman, H.M. (2002). Metal-Catalyzed Steam Reforming of Ethanol in the Production of Hydrogen for Fuel Cell Applications. Applied Catalysis B: Environmental, Vol.39, No.1, (November 2002), pp. 65-74, ISSN 0926-3373

[39] Sheng, P.Y., Idriss, H. (2004). Ethanol Reactions over Au-Rh/ $\mathrm{CeO}_{2}$ Catalysts. Total Decomposition and $\mathrm{H}_{2}$ Formation. Journal of Vacuum Science and Technology A, Vol.22, No.4, (July 2004), pp. 1652-1658, ISSN 0734-2101 
[40] Kuga, J., Subramani, V., Song, C., Engelhard, M.H., Chin, Y. (2006). Effects of Nanocrystalline $\mathrm{CeO}_{2}$ Supports on the Properties and Performance of Ni-Rh Bimetallic Catalyst for Oxidative Steam Reforming of Ethanol. Journal of Catalysis, Vol.238, No.2, (March 2006), pp.430-440, ISSN 0021-9517

[41] Cavallaro, S., Chiodo, V., Freni, S., Mondello, N., Frusteri, F. (2003). Performance of $\mathrm{Rh} / \mathrm{Al}_{2} \mathrm{O}_{3}$ Catalyst in the Steam Reforming of Ethanol: $\mathrm{H}_{2}$ Production for MCFC. Applied Catalysis A: General, Vol.249, No.1, (August 2003), pp. 119-128, ISSN 0926$860 \mathrm{X}$

[42] Rogatis, L.D., Montini, T., Casula, M.F., Fornasiero, P. (2008). Design of $\mathrm{Rh} @ \mathrm{Ce}_{0.2} \mathrm{Zr}_{0.8} \mathrm{O}_{2}-\mathrm{Al}_{2} \mathrm{O}_{3}$ Nanocomposite for Ethanol Steam Reforming. Journal of Alloys and Compounds, Vol.451, No.1-2, (February 2008), pp. 516-520, ISSN 09258388

[43] Frusteri, F., Freni, S., Spadaro, L., Chiodo, V., Bonura, G., Donato, S. (2004). $\mathrm{H}_{2}$ Production for MC Fuel Cell by Steam Reforming of Ethanol over MgO Supported $\mathrm{Pd}, \mathrm{Rh}, \mathrm{Ni}$, and Co Catalysts. Catalysis Communications, Vol.5, No.10, (October 2004), pp. 611-615, ISSN 1566-7367

[44] Montini, T., Rogatis, L.D., Gombac, V., Fornasiero, P. (2007). Rh(1\%)@Ce $\mathrm{Zr}_{1-\mathrm{x}} \mathrm{O}_{2}-\mathrm{Al}_{2} \mathrm{O}_{3}$ Nanocomposites: Active and Stable Catalysts for Ethanol Steam Reforming. Applied Catalysis B: Environmental, Vol.71, No.3-4, (February 2007), pp. 125-134, ISSN 0926-3373

[45] Diagne, C., Idriss, H., Kiennemann, A. (2002). Hydrogen Production by Ethanol Reforming over $\mathrm{Rh} / \mathrm{CeO}_{2}-\mathrm{ZrO}_{2}$ Catalysts. Catalysis Communications, Vol.3, No.12, (December 2002), pp. 565-571, ISSN 1566-7367

[46] Auprêtre, F., Descorme, C., Duprez, D. (2002). Bio-Ethanol Catalytic Steam Reforming over Supported Metal Catalysts. Catalysis Communications, Vol.3, No.6, (June 2002), pp. 263-267, ISSN 1566-7367

[47] Yang, Y., Ma, J., Wu, F. (2006). Production of Hydrogen by Steam Reforming of Ethanol over a Ni/ZnO Catalyst. International Journal of Hydrogen Energy, Vol.31, No.7, (June 2006), pp. 877-882, ISSN 0360-3199

[48] Sun, J., Qiu, X., Wu, F., Zhu, W. (2005). H2 from Steam Reforming of Ethanol at Low Temperature over Ni/Y2O3, Ni/La2O3, and Ni/A12O3 Catalysts for Fuel Cell Application. International Journal of Hydrogen Energy, Vol.30, No.4, (March 2005), pp. 437-445, ISSN 0360-3199

[49] Fatsikostas, A.N., Kondarides, D.I., Verykios, X.E. (2002). Production of Hydrogen for Fuel Cells by Reformation of Biomass-Derived Ethanol. Catalysis Today, Vol.75, No.1-4, (July 2002), pp. 145-155, ISSN 0920-5861

[50] Fatsikostas, A.N., Verykios, X.E. (2004). Reaction Network of Steam Reforming of Ethanol over Ni-Based Catalysts. Journal of Catalysis, Vol.225, No.2, (July 2004), pp.439-452, ISSN 0021-9517

[51] Frusteri, F., Freni, S., Chiodo, V., Spadaro, L., Bonura, G., Cavallaro, S. (2004). Patassium Improved Stability of $\mathrm{Ni} / \mathrm{MgO}$ in the Steam Reforming of Ethanol for the Production of Hydrogen for MCFC. Journal of Power Sources, Vol.132, No.1-2, (May 2004), pp. 139-144, ISSN 0378-7753 
[52] Biswas, P., Kunzru, D. (2008). Oxidative Steam Reforming of Ethanol over $\mathrm{Ni} / \mathrm{CeO}_{2}-$ $\mathrm{ZrO}_{2}$ Catalyst. Chemical Engineering Journal, Vol.136, No.1., (February 2008), pp. 4149, ISSN 1385-8947

[53] Biswas, P., Kunzru, D. (2007). Steam Reforming of Ethanol for Production of Hydrogen over $\mathrm{Ni} / \mathrm{CeO}_{2}-\mathrm{ZrO}_{2}$ Catalyst: Effect of Support and Metal Loading. International Journal of Hydrogen Energy, Vol.32, No.8, (June 2007), pp. 969-980, ISSN 0360-3199

[54] Srinivas, D., Satyanarayana, C.V.V., Potdar, H.S., Ratnasamy, P. (2003). Structural Studies on $\mathrm{Ni}-\mathrm{CeO}_{2}-\mathrm{ZrO}_{2}$ Catalysts for Steam Reforming of Ethanol. Applied Catalysis A: General, Vol.246, No.2, (June 2003), pp. 323-334, ISSN 0926-860X

[55] Benito, M., Padilla, R., Rodríguez, L., Sanz, J.L., Daza, L. (2007). Zirconia Supported Catalysts for Bioethanol Steam Reforming : Effect of Active Phase and Zirconia Structure. Journal of Power Sources, Vol.169, No.1, (June 2007), pp. 167-176, ISSN 0378-7753

[56] Fierro, V., Akdim, O., Mirodatos, C. (2003). On-Board Hydrogen Production in A Hybrid Electric Vehicle by Bio-Ethanol Oxidative Steam Reforming over Ni and Noble Metal Based Catalysts. Green Chemistry, Vol.5, No.1., (January 2003), pp. 2024, ISSN 1463-9270

[57] Marino, J.F., Cerrella, E.G., Duhalde, S., Jobbagy, M., Laborde, M.A. (1998). Hydrogen from Steam Reforming of Ethanol. Characterization and Performance of CopperNickel Supported Catalysts. International Journal of Hydrogen Energy, Vol.23, No.12, (December 1998), pp. 1095-1101, ISSN 0360-3199

[58] Velu, S., Satoh, N., Gopinath, C.S., Suzuki, K. (2002). Oxidative Reforming of BioEthanol over CuNiZnAl Mixed Oxide Catalysts for Hydrogen Production. Catalysis Letters, Vol.82, No.1-2, (September 2002), pp. 145-152, ISSN 1011-372X

[59] Haga, F., Nakajima, T., Miya, H., Mishima, S. (1997). Catalytic Properties of Supported Cobalt Catalysts for Steam Reforming of Ethanol. Catalysis Letters, Vol.48, No.3-4, (October 1997), pp. 223-227, ISSN 1011-372X

[60] Haga, F., Nakajima, T., Miya, H., Mishima, S. (1998). Effect of Crystallite Size on the Catalysis of Alumina-Supported Cobalt Catalyst for Steam Reforming of Ethanol. Reaction Kinetics and Catalysis Letters, Vol.63, No.2, (March 1998), pp. 253-259, ISSN 0133-1736

[61] Llorca, J., Piscina, P.R., Sales, J., Homs, N. (2001). Direct Production of Hydrogen from Ethanolic Aqueous Solutions over Oxide Catalysts. Chemical Communications, Vol.7, No.1, (March 2001), pp. 641-642, ISSN 1359-7345

[62] Mielenz, J.R. (2001). Ethanol Production from Biomass: Technology and Commercialization Status. Current Opinion in Microbiology, Vol.4, No.3, (June 2001), pp. 324-329, ISSN 1369-5274

[63] Homs, N., Llorca, J., Piscina, P.R. (2006). Low-Temperature Steam-Reforming of Ethanol over ZnO-Supported $\mathrm{Ni}$ and $\mathrm{Cu}$ Catalysts: The Effect of Nickel and Copper Addition to ZnO-Supported Cobalt-Based Catalysts. Catalysis Today, Vol.116, No.3, (August 2006), pp. 361-366, ISSN 0920-5861

[64] Galetti, A.E., Gomez, M.F., Arrua, L.A., Marchi, A.J., Abello, M.C. (2008). Study of $\mathrm{CuCoZnAl}$ Oxide as Catalyst for the Hydrogen Production from Ethanol 
Reforming. Catalysis Communications, Vol.9, No.6, (March 2008), pp. 1201-1208, ISSN 1566-7367

[65] Llorca, J., Homs, N., Sales, J., Piscina, P.R. (2002). Efficient Production of Hydrogen over Supported Cobalt Catalysts from Ethanol Steam Reforming. Journal of Catalysis, Vol.209, No.2, (July 2002), pp.306-317, ISSN 0021-9517

[66] Wang, H., Ye, J.L., Liu, Y., Li, Y.D., Qin, Y.N. (2007). Steam Reforming of Ethanol over Co3O4/CeO2 Catalysts Prepared by Different Methods. Catalysis Today, Vol.129, No.3-4, (December 2007), pp. 305-312, ISSN 0920-5861

[67] Zhang, B., Tang, X., Li, Y., Xu, Y., Shen, W. (2007). Hydrogen Production from Steam Reforming of Ethanol and Glycerol over Ceria-Supported Metal Catalysts. International Journal of Hydrogen Energy, Vol.32, No.13, (September 2007), pp. 23672373, ISSN 0360-3199

[68] Zhang, B., Tang, X., Li, Y., Xu, Y., Shen, W. (2006). Steam Reforming of Bio-Ethanol for the Production of Hydrogen over Ceria-Supported Co, Ir, and Ni Catalysts. Catalysis Communications, Vol.7, No.6, (June 2006), pp. 367-372, ISSN 1566-7367

[69] Song, H., Zhang, L., Watson, R.B., Braden, D., Ozkan, U.S. (2007). Investigation of BioEthanol Steam Reforming over Cobalt-Based Catalysts. Catalysis Today, Vol.129, No.3-4, (December 2007), pp. 346-354, ISSN 0920-5861

[70] Bellido, J.D.A., Assaf, E.M. (2008). Nickel Catalysts Supported on $\mathrm{ZrO}_{2}, \mathrm{Y}_{2} \mathrm{O}_{3}$-Stablized $\mathrm{ZrO}_{2}$ and CaO-Stablized $\mathrm{ZrO}_{2}$ for the Steam Reforming of Ethanol: Effect of the Support and Nickel Load. Journal of Power Sources, Vol.177, No.1, (February 2008), pp. 24-32, ISSN 0378-7753

[71] Rodriguez, J.A., Wang, X., Hanson, J.C., Liu, G. (2003). The Behavior of Mixed-Metal Oxides: Structural and Electronic Properties of $\mathrm{Ce}_{1-\mathrm{x}} \mathrm{Ca}_{\mathrm{x}} \mathrm{O}_{2}$ and $\mathrm{Ce}_{1-\mathrm{x}} \mathrm{Ca}_{\mathrm{x}} \mathrm{O}_{2-\mathrm{x}}$. The Journals of Chemical Physics, Vol.119, No.11, (September 2003), pp. 5659-5669, ISSN 0021-9606

[72] Urasaki, K., Tokunaga, K., Sekine, Y., Matsukata, M., Kikuchi, E. (2008). Production of Hydrogen by Steam Reforming of Ethanol over Cobalt and Nickel Catalysts Supported on Perovskite-Type Oxides. Catalysis Communications, Vol.9, No.5, (March 2008), pp. 600-604, ISSN 1566-7367

[73] Natile, M. M., Poletto, F., Galenda, A., Glisenti, A., Montini, T., Rogatis, L. De and Fornasiero, P. (2008). $\mathrm{La}_{0.6} \mathrm{Sr}_{0.4} \mathrm{Co}_{1-\mathrm{y}} \mathrm{Fe}_{\mathrm{y}} \mathrm{O}_{3-\delta}$ Perovskites: Influence of the $\mathrm{Co} / \mathrm{Fe}$ Atomic Ratios on Properties and Catalytic Activity toward Alchol SteamReforming. Chemistry of Materials, Vol.20, No.6, (February 2008), pp. 2314-2327, ISSN 0897-4756

[74] Llorca, J., Piscina, P.R., Dalmon, J., Sales, J., Homs, N. (2003). CO-Free Hydrogen from Steam-Reforming of Bioethanol over ZnO-Supported Cobalt Catalysts: Effect of the Metallic Precursor. Applied Catalysis B: Environmental, Vol.43, No. 4, (July 2003), pp. 355-369, ISSN 0926-3373

[75] Panpranot, J., Kaewkun, S., Praserthdam, P., Goodwin, J.G. (2003). Effect of Cobalt Precursors on the Dispersion of Cobalt on MCM-41. Catalysis Letters, Vol.91, No.1-2, (November 2003), pp. 95-102, ISSN 1011-372X

[76] Batista, M.S., Santos, R.K.S., Assaf, E.M., Assaf, J.M., Ticianelli, E.A. Characterization of the Activity and Stability of Supported Cobalt Catalysts for the Steam Reforming of 
Ethanol. Journal of Power Sources, Vol.124, No.1, (October 2003), pp. 99-103, ISSN 0378-7753

[77] Song, S., Akande, A.J., Idem, R.O., Mahinpey, N. (2007). Inter-Relationshiop Between Preparation Methods, Nickel Loading, Characteristics and Performance in the Reforming of Crude Ethanol over $\mathrm{Ni} / \mathrm{Al}_{2} \mathrm{O}_{3}$ Catalysts: A Neural Network Approach. Engineering Applications of Artificial Intelligence, Vol.20, No.2, (March 2007), pp. 261-271, ISSN 0952-1976

[78] Ho, S., Su, Y. (1997). Effect of Ethanol Impregnation on the Properties of SilicaSupported Cobalt Catalysts. Journal of Catalysis, Vol.168, No.1, (May 1997), pp. 5159, ISSN 0021-9517

[79] Enache, D.I., Rebours, B., Auberger, M.R., Revel, R. (2002). In-Situ XRD Study of the Influence of Thermal Treatment on the Characteristics and the Catalytic Properties of Cobalt-Based Fischer-Tropsch Catalysts. Journal of Catalysis, Vol.205, No.2, (January 2002), pp. 346-353, ISSN 0021-9517

[80] Ruckenstein, E., Wang, H.Y. (2000). Effect of Calcinations on the Species Formed and the Reduction Behavior of the Cobalt-Magnesia Catalysts. Catalysis Letters, Vol.70, No.1-2, (December 2000), pp. 15-21, ISSN 1011-372X

[81] Llorca, J., Homs, N., Sales, J., Fierro, J.G., Piscina, P.R. (2004). Effect of Sodium Addition on the Performance of Co-ZnO-Based Catalysts for Hydrogen Production from Bioethanol. Journal of Catalysis, Vol.222, No.2, (March 2004), pp. 470-480, ISSN 00219517

[82] Jacobs, G., Das, T.K., Zhang, Y., Li, J. (2002). Fischer-Tropsch Synthesis: Support, Loading, and Promoter Effects on the Reduciblity of Cobalt Catalysts. Applied Catalysis A: General, Vol.233, No.1-2, (July 2002), pp. 263-281, ISSN 0926-860X

[83] Huang, L., Xu, Y. (2002). Studies on the Interaction Between Ruthenium and Cobalt in Supported Catalysts in Favor of Hydroformylation. Catalysis Letters, Vol.69, No.3-4, (November 2002), pp. 145-151, ISSN 1011-372X

[84] Profeti, L.P.R., Ticianelli, E.A., Assaf, E.M. (2008). Production of Hydrogen by Ethanol Steam Reforming on $\mathrm{Co} / \mathrm{Al}_{2} \mathrm{O}_{3}$ Catalysts: Effect of Addition of Small Quantities of Noble Metals. Journal of Power Sources, Vol.175, No.1, (January 2008), pp. 482-489, ISSN 0378-7753

[85] Soled, S.L., Iglesia, E., Fiato, R.A., Baumgartner, J.E., Vroman, H. (2003). Control of Metal Dispersion and Structure by Changes in the Solid-State Chemistry of Supported Cobalt Fischer-Tropsch Catalysts. Topics in Catalysis, Vol.26, No.1-4, (December 2003), pp. 101-109, ISSN 1022-5528

[86] Hu, X., Lu, G. (2007). Investigation of Steam Reforming of Acetic Acid to Hydrogen over Ni-Co Metal Catalyst. Journal of Molecular Catalysis A : Chemical, Vol.261, No.1, (January 2007), pp. 43-48, ISSN 1381-1169

[87] Torres, J.A., Llorca, J., Casanovas, A., Domínguez, M., Salvadó, J., Montané, D. (2007). Steam Reforming of Ethanol at Moderate Temperature: Multifactorial Design Analysis of $\mathrm{Ni} / \mathrm{La}_{2} \mathrm{O}_{3}-\mathrm{Al}_{2} \mathrm{O}_{3}$, and $\mathrm{Fe}$ - and Mn-Promoted $\mathrm{Co} / \mathrm{ZnO}$ Catalysts. Journal of Power Sources, Vol.169, No.1, (July 2007), pp. 158-166, ISSN 0378-7753

[88] Mattos, L.V., Noronha, F.B. (2005). The Influence of the Nature of the Metal on the Performance of Cerium Oxide Supported Catalysts in the Partial Oxidation of 
Ethanol. Journal of Power Sources, Vol.152, No.1, (December 2005), pp. 50-59, ISSN 0378-7753

[89] Llorca, J., Dalmon, J., Piscina, P.R., Homs, N. (2003). In Situ Magnetic Characterization of Supported Cobalt Catalysts under Steam Reforming of Ethanol. Applied Catalysis A: General, Vol.243, No.2, (April 2003), pp. 261-269, ISSN 0926-860X

[90] Guil, J.M., Homs, N., Llorca, J., Piscina, P.R. (2005). Microcalorimetric and Infrared Studies of Ethanol and Acetaldehyde Adsorption to Investigate the Ethanol Steam Reforming on Supported Cobalt Catalysts. Journal of Physical Chemistry B, Vol.109, No.21, (May 2005), pp. 10813-10819, ISSN 1520-6106

[91] Batista, M.S., Santos, R.K.S., Assaf, E.M., Assaf, J.M., Ticianelli, E.A. (2004). High Efficiency Steam Reforming of Ethanol by Cobalt-Based Catalysts. Journal of Power Sources, Vol.134, No.1, (July 2004), pp. 27-32, ISSN 0378-7753

[92] Idriss, H., Diagne, C., Hindermann, J.P., Kiennemann, A., Barteau, M.A. (1995). Reactions of Acetaldehyde on $\mathrm{CeO}_{2}$ and $\mathrm{CeO}_{2}$-Supported Catalysts. Journal of Catalysis, Vol.155, No.2, (September 1995), pp. 219-237, ISSN 0021-9517

[93] Tuti, S., Pepe, F. (2008). On the Catalytic Activity of Cobalt Oxide for the Steam Reforming of Ethanol. Catalysis Letters, Vol.122, No.1-2, (April 2008), pp. 196-203, ISSN 1011-372X

[94] Kaddouri, A., Mazzocchia, C. (2004). A Study of the Influence of the Synthesis Conditions upon the Catalytic Properties of $\mathrm{Co} / \mathrm{SiO}_{2}$ or $\mathrm{Co} / \mathrm{Al}_{2} \mathrm{O}_{3}$ Catalysts Used for Ethanol Steam Reforming. Catalysis Communications, Vol.5, No.6, (June 2004), pp. 339-345, ISSN 1566-7367

[95] Vargas, J.C., Libs, S., Roger, A., Kiennemann, A. (2005). Study of Ce-Zr-Co FluoriteType Oxide as Catalysts for Hydrogen Production by Steam Reforming of Bioethanol. Catalysis Today, Vol.107-108, No.1, (October 2005), pp. 417-425, ISSN 0920-5861

[96] Hsiao, W., Lin, Y., Chen, Y., Lee, C. (2007). The Effect of the Morphology of Nanocrystalline $\mathrm{CeO}_{2}$ on Ethanol Reforming. Chemical Physics Letters, Vol.441, No.4-6, (June 2007), pp. 294-299, ISSN 0009-2614

[97] Sun, C., Sun, J., Xiao, G., Zhang, H., Qiu, X., Li, H., Chen, L. (2006). Mesoscale Organization of Nearly Monodisperse Flowerlike Ceria Microspheres. Journal of Physical Chemistry B, Vol.110, No.27, (June 2006), pp. 13445-13452, ISSN 1520-6106

[98] Gu, F., Wang, Z., Han, D., Shi, C., Guo, G. (2007). Reverse Micelles Directed Synthesis of Mesoporous Ceria Nanostructures. Materials Science and Engineering: B, Vol.139, No.1, (April 2007), pp. 62-68, ISSN 0921-5107

[99] Song, H., Zhang, L., Ozkan, U.S. (2007). Effect of Synthesis Parameters on the Catalytic Activity of $\mathrm{Co}-\mathrm{ZrO}_{2}$ for Bio-Ethanol Steam Reforming. Green Chemistry, Vol.9, No.6., (June 2007), pp. 686-694, ISSN 1463-9270

[100] Song, H., Ozkan, U.S. (2009). Ethanol Steam Reforming over Co-Based Catalysts: Role of Oxygen Mobility. Journal of Catalysis, Vol.261, No.1, (January 2009), pp. 66-74, ISSN 0021-9517

[101] Song, H., Ozkan, U.S. (2010). The Role of Impregnation Medium on the Activity of Ceria-Supported Cobalt Catalysts for Ethanol Steam Reforming. Journal of Molecular Catalysis A : Chemical, Vol.318, No.1-2, (March 2010), pp. 21-29, ISSN 1381-1169 
[102] Song, H., Ozkan, U.S. (2010). Changing the Oxygen Mobility in Co/Ceria Catalysts by Ca Incorporation: Implications for Ethanol Steam Reforming. Journal of Physical Chemistry A, Vol.114, No.11, (May 2010), pp. 3796-3801, ISSN 1089-5639

[103] Song, H., Mirkelamoglu, B., Ozkan, U.S. (2010). Effect of Cobalt Precursor on the Performance of Ceria-Supported Cobalt Catalysts for Ethanol Steam Reforming. Applied Catalysis A: General, Vol.382, No.1, (June 2010), pp. 58-64, ISSN 0926-860X

[104] Song, H., Tan, B., Ozkan, U.S. (2009). Novel Synthesis Techniques for Preparation of $\mathrm{Col} / \mathrm{CeO}_{2}$ as Ethanol Steam Reforming Catalysts. Catalysis Letters, Vol.132, No.3-4, (October 2009), pp. 422-429, ISSN 1011-372X

[105] Sánchez, M.C., Navarro, R.M., Fierro, J.L.G. (2007). Ethanol Steam Reforming over $\mathrm{Ni} / \mathrm{M}_{\mathrm{x}} \mathrm{O}_{\mathrm{y}}-\mathrm{Al}_{2} \mathrm{O}_{3}(\mathrm{M}=\mathrm{Ce}, \mathrm{La}, \mathrm{Zr}$ and $\mathrm{Mg})$ Catalysts: Influence of Support on the Hydrogen Production. International Journal of Hydrogen Energy, Vol.32, No.10-11, (July-August 2007), pp. 1462-1471, ISSN 0360-3199

[106] Sánchez, M.C., Navarro, R.M., Fierro, J.L.G. (2007). Ethanol Steam Reforming over $\mathrm{Ni} / \mathrm{La}-\mathrm{Al}_{2} \mathrm{O}_{3}$ Catalysts: Influence of Lanthanum Loading. Catalysis Today, Vol.129, No.3-4, (December 2007), pp. 336-345, ISSN 0920-5861

[107] Freni, S., Cavallaro, S., Mondello, N., Spadaro, L., Frusteri, F. (2003). Production of Hydrogen for MC Fuel Cell by Steam Reforming of Ethanol over MgO Supported Ni and Co Catalysts. Catalysis Communications, Vol.4, No.6, (June 2003), pp. 259-268, ISSN 1566-7367

[108] Casanovas, A, Gerons, M.S., Griffon, F., Llorca, J. (2008). Autothermal Generation of Hydrogen from Ethanol in a Microreactor. International Journal of Hydrogen Energy, Vol.33, No.7, (April 2008), pp. 1827-1833, ISSN 0360-3199

[109] Deluga, G.A., Salge, J.R., Schmidt, L.D., Verykios, X.E. (2004). Renewable Hydrogen from Ethanol by Autothermal Reforming. Science, Vol.303, No.13, (February 2004), pp. 993-997, ISSN 0036-8075

[110] Mariño, F, Baronetti, M.G., Laborde, M. (2004). Hydrogen Production via Catalytic Gasification of Ethanol. A Mechanism Proposal over Copper-Nickel Catalysts. International Journal of Hydrogen Energy, Vol.29, No.1, (January 2004), pp. 67-71, ISSN 0360-3199

[111] Benito, M., Sanz, J.L., Isabel, R., Padilla, R., Arjona, R., Dazaa, L. (2005). Bio-Ethanol Steam Reforming: Insights on the Mechanism for Hydrogen Production. Journal of Power Sources, Vol.151, No.1, (October 2005), pp. 11-17, ISSN 0378-7753

[112] Dömök, M., Tóth, M., Raskó, J., Erdőhelyi, A. (2007). Adsorption and Reactions of Ethanol and Ethanol-Water Mixture on Alumina-Supported Pt Catalysts. Applied Catalysis B: Environmental, Vol.69, No.3-4, (January 2007), pp. 262-272, ISSN 09263373

[113] Erdőhelyi, A., Raskó, J., Kecskés, T., Tóth, M. (2006). Hydrogen Formation in Ethanol Reforming on Supported Noble Metal Catalysts. Catalysis Today, Vol.116, No.3, (August 2006), pp. 367-376, ISSN 0920-5861

[114] Jacobs, G., Keogh, R.A., Davis, B.H. (2007). Steam Reforming of Ethanol over Pt/Ceria with Co-Fed Hydrogen. Journal of Catalysis, Vol.245, No.2, (January 2007), pp. 326337, ISSN 0021-9517 
[115] Raskó, J., Dömök, M., Baán, K., Erdóhelyi, A. (2006). FTIR and Mass Spectrometric Study of the Interaction of Ethanol and Ethanol-Water with Oxide-Supported Platinum Catalysts. Applied Catalysis A: General, Vol.299, No.1, (January 2006), pp. 202-211, ISSN 0926-860X

[116] Resinia, C., Cavallaro, S., Frusteri, F., Freni, S. (2007). Initial Steps in the Production of $\mathrm{H}_{2}$ from Ethanol: A FT-IR Study of Adsorbed Species on Ni/MgO Catalyst Surface. Reaction Kinetics and Catalysis Letters, Vol.90, No.1, (February 2007), pp. 117-126, ISSN 0133-1736

[117] Chung, M., Moon, D., Kim, H., Park, K., Ihm, S. (1996). Higher Oxygenate Formation from Ethanol on $\mathrm{Cu} / \mathrm{ZnO}$ Catalysts: Synergism and Reaction Mechanism. Journal of Molecular Catalysis A : Chemical, Vol.113, No.3, (December 1996), pp. 507-515, ISSN 1381-1169

[118] Pfeifer, P., Kölbl, A., Schubert, K. (2005). Kinetic Investigations on Methanol Steam Reforming on PdZn Catalysts in Microchannel Reactors and Model Transfer into the Pressure Gap Region. Catalysis Today, Vol.110, No.1-2, (December 2005), pp. 7685, ISSN 0920-5861

[119] Frank, B., Jentoft, F.C., Soerijanto, H., Kröhnert, J., Schlögl, R., Schomäcker, R. (2007). Steam Reforming of Methanol over Copper-Containing Catalysts: Influence of Support Material on Microkinetics. Journal of Catalysis, Vol.246, No.1, (February 2007), pp. 177-192, ISSN 0021-9517

[120] Patel, S., Pant, K.K. (2007). Experimental Study and Mechanistic Kinetic Modeling for Selective Production of Hydrogen via Catalytic Steam Reforming of Methanol. Chemical Engineering Science, Vol.62, No.18-20, (September-October 2007), pp. 54255435, ISSN 0009-2509

[121] Mastalir, A., Frank, B., Szizybalski, A., Soerijanto, H., Deshpande, A., Niederberger, M., Schomäcker, R., Schlögl, R., Ressler, T. (2005). Steam Reforming of Methanol over $\mathrm{Cu} / \mathrm{ZrO}_{2} / \mathrm{CeO}_{2}$ Catalysts: A Kinetic Study. Journal of Catalysis, Vol.230, No.2, (March 2005), pp. 464-475, ISSN 0021-9517

[122] Peppley, B.A., Amphlett, J.C., Kearns, L.M., Mann, R.F. (1999). Methanol-Steam Reforming on $\mathrm{Cu} / \mathrm{ZnO} / \mathrm{Al}_{2} \mathrm{O}_{3}$ Catalysts. Part 2. A Comprehensive Kinetic Model. Applied Catalysis A: General, Vol.179, No.1-2, (April 1999), pp. 31-49, ISSN 0926-860X

[123] Hou, K., Hughes, R. (2001). The Kinetics of Methane Steam Reforming over A Ni/a$\mathrm{Al}_{2} \mathrm{O}_{3}$ Catalyst. Chemical Engineering Science, Vol.82, No.1-3, (March 2001), pp. 311328, ISSN 0009-2509

[124] Craciun, R., Shereck, B., Gorte, R.J. (1998). Kinetic Studies of Methane Steam Reforming on Ceria-Supported Pd. Catalysis Letters, Vol.51, No.3-4, (May 1998), pp. 149-153, ISSN 1011-372X

[125] Hoang, D.L., Chan, S.H., O.L. Ding, O.L. (2005). Kinetics and Modeling Study of Methane Steam Reforming over Sulfide Nickel Catalyst on A Gamma Alumina Support. Chemical Engineering Science, Vol.112, No.1-3, (September 2005), pp. 1-11, ISSN 0009-2509

[126] Laosiripojana, N., Assabumrungrat, S. (2005). Methanol Steam Reforming over Ni/Ce$\mathrm{ZrO}_{2}$ Catalyst: Influences of Ce- $\mathrm{ZrO}_{2}$ Support on Reactivity, Resistance toward 
Carbon Formation, and Intrinsic Reaction Kinetics. Applied Catalysis A: General, Vol.290, No.1-2, (August 2005), pp. 200-211, ISSN 0926-860X

[127] Berman, A., Karn, R.K., Epstein, M. (2005). Kinetics of Steam Reforming of Methane on $\mathrm{Ru} / \mathrm{Al}_{2} \mathrm{O}_{3}$ Catalyst Promoted with Mn Oxides. Applied Catalysis A: General, Vol.282, No.1-2, (March 2005), pp. 73-83, ISSN 0926-860X

[128] Akande, A., Aboudheir, A., Idema, R., Dalai, A. (2006). Kinetic Modeling of Hydrogen Production by the Catalytic Reforming of Crude Ethanol over A Co-Precipitated Ni-A12O3 Catalyst in A Packed Bed Tubular Reactor. International Journal of Hydrogen Energy, Vol.31, No.12, (September 2006), pp. 1707-1715, ISSN 0360-3199

[129] Therdthianwong, A., Sakulkoakiet, T., Therdthianwong, S. (2001). Hydrogen Production by Catalytic Ethanol Steam Reforming. ScienceAsia, Vol.27, No.3, (September 2001), pp. 193-198, ISSN 1513-1874

[130] Vaidya, P.D., Rodrigues, A.E. (2006). Kinetics of Steam Reforming of Ethanol over A $\mathrm{Ru} / \mathrm{Al}_{2} \mathrm{O}_{3}$ Catalyst. Industrial \& Engineering Chemistry Research, Vol.45, No.19, (September 2006), pp. 6614-6618, ISSN 0888-5885

[131] Sahoo, D.R., Vajpai, S., Patel, S., Pant, K.K. (2007). Kinetic Modeling of Steam Reforming of Ethanol for the Production of Hydrogen over $\mathrm{Co} / \mathrm{Al}_{2} \mathrm{O}_{3}$ Catalyst. Chemical Engineering Science, Vol.125, No.3, (January 2007), pp. 139-147, ISSN 00092509

[132] Mathure, P.V., Ganguly, S., Patwardhan, A.V., Saha, R.K. (2007). Steam Reforming of Ethanol Using a Commercial Nickel-Based Catalyst. Industrial \& Engineering Chemistry Research, Vol.46, No.25, (December 2007), pp. 8471-8479, ISSN 0888-5885

[133] Song, H., Bao, X., Hadad, C., Ozkan, U.S. (2011). Adsorption/Desorption Behavior of Ethanol Steam Reforming Reactants and Intermediates over Supported Cobalt Catalysts. Catalysis Letters, Vol.141, No.1, (January 2011), pp. 43-54, ISSN 1011-372X

[134] Lima, S.M., Silva, A.M., Graham, U.M., Jacobs, G., Davis, B.H., Mattos, L.V., Noronha, F.B. (2009). Ethanol Decomposition and Steam Reforming of Ethanol over $\mathrm{CeZrO}_{2}$ and $\mathrm{Pt} / \mathrm{CeZrO} 2$ Catalyst: Reaction Mechanism and Deactivation. Applied Catalysis A: General, Vol.352, No.1-2, (January 2009), pp. 95-113, ISSN 0926-860X

[135] Vesselli, E., Coslovich, G., Comelli, G., Rosei, R. (2005). Modelling of Ethanol Decomposition on $\mathrm{Pt}(111)$ : A Comparison with Experiment and Density Functional Theory. Journal of Physics: Condensed Matter, Vol.17, No.39, (October 2005), pp. 61396148, ISSN 0953-8984

[136] Yang, M., Bao, X., Li, W. (2007). First Principle Study of Ethanol Adsorption and Formation of Hydrogen Bond on Rh(111) Surface. Journal of Physical Chemistry C, Vol.111, No.20, (May 2007), pp. 7403-7410, ISSN 1932-7447

[137] Fartaria, R., Freitas, F., Fernandes, F. (2007). A Force Field for Simulating Ethanol Adsorption on $\mathrm{Au}(111)$ Surfaces. A DFT Study. International Journal of Quantum Chemistry, Vol.107, No.11, (May 2007), pp. 2169-2177, ISSN 1097-461X

[138] Pozzo, M., Carlini, G., Rosei, R., Alfè, D. (2007). Comparative Study of Water Dissociation on $\mathrm{Rh}(111)$ and $\mathrm{Ni}(111)$ Studied with First Principles Calculations. The Journal of Chemical Physics, Vol.126, No.16, (April 2007), pp. 164706-164712, ISSN 0021-9606 
[139] Andersson, K., Nikitn, A., Pettersson, L.G.M., Nilsson, A., Ogasawara, H. (2004). Water Dissociation on $\mathrm{Ru}(001)$ : An Activated Process. Physical Review Letters, Vol.93, No.19, (November 2004), pp. 196101-196104, ISSN 0031-9007

[140] Chen, H., Liu, S., Ho, J. (2006). Theoretical Calculation of the Dehydrogenation of Ethanol on A Rh/ $\mathrm{CeO}_{2}$ Surface. Journal of Physical Chemistry B, Vol.110, No.30, (August 2006), pp. 14816-14823, ISSN 1520-6106

[141] Wang, J., Lee, C.S., Lin, M.C. (2009). Mechanism of Ethanol Reforming : Theoretical Foundations. Journal of Physical Chemistry C, Vol.113, No.16, (April 2009), pp. 66816688, ISSN 1932-7447

[142] Chiang, H., Wang, C., Cheng, Y., Jiang, J., Hsieh, H. (2010). Density Functional Theory Study of Ethanol Decomposition on $3 \mathrm{Ni} / \mathrm{a}-\mathrm{Al}_{2} \mathrm{O}_{3}(0001)$ Surface. Langmuir, Vol.26, No.20, (October 2010), pp. 15845-15851, ISSN 0742-7463

[143] Li, H., Chen, H., Peng, S., Ho, J. (2009). Dehydrogenation of Ethanol on An $\mathrm{O}_{2-}$ 4Rh/ $\mathrm{CeO}_{2-\mathrm{x}}(111)$ Surface: A Computational Study. Chemical Physics, Vol.359, No.13, (May 2009), pp. 141-150, ISSN 0301-0104

[144] Wu, S., Lia, Y., Ho, J., Hsieh, H. (2009). Density Functional Studies of Ethanol Dehydrogenation on A $2 \mathrm{Rh} / \mathrm{v}-\mathrm{Al}_{2} \mathrm{O}_{3}(110)$ Surface. Journal of Physical Chemistry C, Vol.113, No.36, (September 2009), pp. 16181-16187, ISSN 1932-7447

[145] Li, M., Guo, W., Jiang, R., Zhao, L., Shan, H. (2010). Decomposition of Ethanol on Pd(111): A Density Functional Theory Study. Langmuir, Vol.26, No.3, (February 2010), pp. 1879-1888, ISSN 0742-7463

[146] Phatak, A., Delgass, W., Ribeiro, F., Schneider, W. (2009). Density Functional Theory Comparison of Water Dissociation Steps on $\mathrm{Cu}, \mathrm{Au}, \mathrm{Ni}, \mathrm{Pd}$, and Pt. Journal of Physical Chemistry C, Vol.113, No.17, (April 2009), pp. 7269-7276, ISSN 1932-7447

[147] Kresse, G, Hafner, J. (1993). Ab Initio Molecular Dynamics for Liquid Metals. Physical Review B, Vol.47, No.1, (January 1993), pp. 558-561, ISSN 1098-0121

[148] Kresse, G., Furthmüller, J. (1996). Efficiency of Ab-Initio Total Energy Calculations for Metals and Semiconductors Using A Plane-Wave Basis Set. Computational Materials Science, Vol.6, No.1, (July 1996), pp. 15-50, ISSN 0927-0256

[149] Kresse, G., Furthmüller, J. (1996). Efficient Iterative Schemes for Ab-Initio Total-Energy Calculations Using A Plane-Wave Basis Set. Physical Review B, Vol.54, No.16, (October 1996), pp. 11169-11186, ISSN 1098-0121

[150] Blöchl, P.E. (1994). Projector Augmented-Wave Method. Physical Review B, Vol.50, No.24, (December 1994), pp. 17953-17979, ISSN 1098-0121

[151] Kresse, G., Joubert, D. (1999). From Ultrasoft Pseudopotentials to the Projector Augumented-Wave Method. Physical Review B, Vol.59, No.3, (January 1999), pp. 1758-1775, ISSN 1098-0121

[152] White, J.A., Bird, D.M. (1994). Implementation of Gradient-Corrected ExchangeCorrelation Potentials in Car-Parrinello Total-Energy Calculations. Physical Review B, Vol.50, No.7, (August 1994), pp. 4954-4957, ISSN 1098-0121

[153] Perdew, J.P., Chevary, J.A., Vosko, S.H., Jackson, K.A., Pederson, M.R., Singh, D.J., Fiolhais, C. (1992). Atoms, Molecules, Solids, and Surfaces: Applications of the Generalized Gradient Approximation for Exchange and Correlation. Physical Review B, Vol.46, No.11, (September 1992), pp. 6671-6687, ISSN 1098-0121 
[154] Clotet, A., Pacchioni, G. (1996). Acetylene on Cu and Pd(111) Surfaces: A Comparative Theoretical Study of Bonding Mechanism, Adsorption Sites, and Vibrational Spectra. Surface Science, Vol.346, No.1-3, (February 1996), pp. 91-107, ISSN 00396028

[155] Ulitsky, A., Elber, R. (1990). A New Technique to Calculate Steepest Descent Paths in Flexible Polyatomic Systems. Journal of Chemical Physics, Vol.92, No.2, (January 1990), pp. 1510-1511, ISSN 0021-9606

[156] Mills, G., Jónsson, H., Schenter, G.K. (1995). Reversible Work Transition State Theory: Application to Dissociative Adsorption of Hydrogen. Surface Science, Vol.324, No.23, (February 1995), pp. 305-337, ISSN 0039-6028

[157] Henkelman, G., Uberuaga, B.P., Jónsson, H. (2000). A Climbing Image Nudged Elastic Band Method for Finding Saddle Points and Minimum Energy Paths. Journal of Chemical Physics, Vol.113, No.22, (December 2000), pp. 9901-9904, ISSN 0021-9606

[158] Song, H, Ozkan, U.S. (2010). Economic Analysis of Hydrogen Production Through A Bio-Ethanol Steam Reforming Process: Sensitivity Analyses and Cost Estimations. International Journal of Hydrogen Energy, Vol.35, No.1, (January 2010), pp. 127-134, ISSN 0360-3199

[159] Cai, W., Wang, F., Veen, A., Descorme, C., Schuurman, Y., Shen, W., Mirodatos, C. (2010). Hydrogen Production from Ethanol Steam Reforming in A Micro-Channel Reactor. International Journal of Hydrogen Energy, Vol.35, No.3, (February 2010), pp. 1152-1159, ISSN 0360-3199

[160] Casanovas, A., Domínguez, M., Ledesma, C., López, E., Llorca, J. (2009). Catalytic Walls and Micro-Devices for Generating Hydrogen by Low Temperature Steam Reforming of Ethanol. Catalysis Today, Vol.143, No.1-2, (May 2009), pp. 32-37, ISSN 0920-5861

[161] Szijjártó, G., Tompos, A., Margitfavi, J. (2011). High-Throughput and Combinatorial Development of Multicomponent Catalysts for Ethanol Steam Reforming. Applied Catalysis A: General, Vol.391, No.1-2, (January 2011), pp. 417-426, ISSN 0926-860X

[162] Duan, S., Senkan, S. (2005). Catalytic Conversion of Ethanol to Hydrogen Using Combinatorial Methods. Industrial \& Engineering Chemistry Research, Vol.44, No.16, (August 2005), pp. 6381-6386, ISSN 0888-5885

[163] Yuan, L., Ye, T., Gong, F., Guo, Q., Torimoto, Y., Yamamoto, M., Li, Q. (2009). Hydrogen Production from the Current-Enhanced Reforming and Decomposition of Ethanol. Energy \& Fuels, Vol.23, No.6, (June 2009), pp. 3103-3112, ISSN 0887-0624

[164] Kinoshita, C.M., Turn, S.Q. (2003). Production of Hydrogen from Bio-Oil Using CaO as $\mathrm{A} \mathrm{CO}_{2}$ Sorbent. International Journal of Hydrogen Energy, Vol.28, No.10, (October 2003), pp. 1065-1071, ISSN 0360-3199

[165] Yu, C., Lee, D., Park, S., Lee, K., Lee, K. (2009). Ethanol Steam Reforming in A Membrane Reactor with Pt-impregnated Knudsen Membranes. Applied Catalysis B: Environmental, Vol.86, No.3-4, (February 2009), pp. 121-126, ISSN 0926-3373

[166] Tosti, S., Basile, A., Borgognoni, F., Capaldo, V., Cordiner, S., Cave, S., Gallucci, F., Rizzello, C., Santucci, A., Traversa, E. (2008). Low-Temperature Ethanol Steam Reforming in A Pd-Ag Membrane Reactor: Part 2. Pt-Based and Ni-Based Catalysts 
and General Comparison. Journal of Membrane Science, Vol.308, No.1-2, (February 2008), pp. 258-263, ISSN 0376-7388

[167] Akande, A., Idem, R., Dalai, A. (2005). Synthesis, Characterization and Performance Evaluation of $\mathrm{Ni} / \mathrm{Al}_{2} \mathrm{O}_{3}$ Catalysts for Reforming of Crude Ethanol for Hydrogen Production. Applied Catalysis A: General, Vol.287, No.2, (June 2005), pp. 159-175, ISSN 0926-860X

[168] Valant, A., Can, F., Bion, N., Duprez, D., Epron, F. (2010). Hydrogen Production from Raw Bioethanol Steam Reforming: Optimization of Catalyst Composition with Improved Stability against Various Impurities. International Journal of Hydrogen Energy, Vol.35, No.10, (May 2010), pp. 5015-5020, ISSN 0360-3199

[169] Papadias, D., Lee, S., Ferrandon, M., Ahmed, S. (2010). An Analytical and Experimental Investigation of High-Pressure Catalytic Steam Reforming of Ethanol in A Hydrogen Selective Membrane Reactor. International Journal of Hydrogen Energy, Vol.35, No.5, (March 2010), pp. 2004-2017, ISSN 0360-3199 


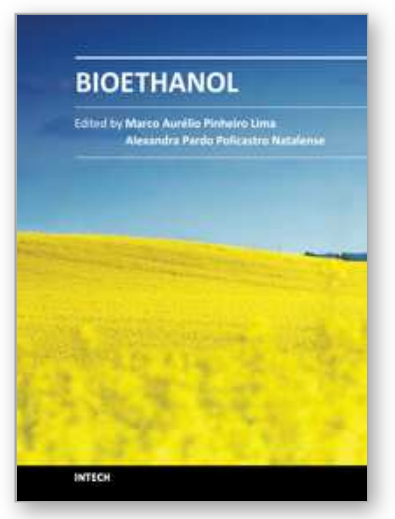

\author{
Bioethanol \\ Edited by Prof. Marco Aurelio Pinheiro Lima
}

ISBN 978-953-51-0008-9

Hard cover, 290 pages

Publisher InTech

Published online 01, February, 2012

Published in print edition February, 2012

Recent studies have shown strong evidence of human activity impact on the climate of the planet. Higher temperatures and intensification of extreme weather events such as hurricanes are among the consequences. This scenario opens up several possibilities for what is now called "green" or low carbon economy. We are talking about creating new businesses and industries geared to develop products and services with low consumption of natural resources and reduced greenhouse gases emission. Within this category of business, biofuels is a highlight and the central theme of this book. The first section presents some research results for first generation ethanol production from starch and sugar raw materials. Chapters in the second section present results on some efforts around the world to develop an efficient technology for producing secondgeneration ethanol from different types of lignocellulosic materials. While these production technologies are being developed, different uses for ethanol could also be studied. The chapter in the third section points to the use of hydrogen in fuel cells, where this hydrogen could be produced from ethanol.

\title{
How to reference
}

In order to correctly reference this scholarly work, feel free to copy and paste the following:

Hua Song (2012). Catalytic Hydrogen Production from Bioethanol, Bioethanol, Prof. Marco Aurelio Pinheiro Lima (Ed.), ISBN: 978-953-51-0008-9, InTech, Available from:

http://www.intechopen.com/books/bioethanol/catalytic-hydrogen-production-from-bioethanol

\section{INTECH}

open science | open minds

\section{InTech Europe}

University Campus STeP Ri

Slavka Krautzeka 83/A

51000 Rijeka, Croatia

Phone: +385 (51) 770447

Fax: +385 (51) 686166

www.intechopen.com

\section{InTech China}

Unit 405, Office Block, Hotel Equatorial Shanghai No.65, Yan An Road (West), Shanghai, 200040, China 中国上海市延安西路65号上海国际贵都大饭店办公楼 405 单元 Phone: +86-21-62489820

Fax: $+86-21-62489821$ 
(C) 2012 The Author(s). Licensee IntechOpen. This is an open access article distributed under the terms of the Creative Commons Attribution 3.0 License, which permits unrestricted use, distribution, and reproduction in any medium, provided the original work is properly cited. 